Collection/Special issue: COST action FP1407

"Understanding wood modification through an integrated scientific and environmental impact approach"

Guest Editors: Giacomo Goli, Andreja Kutnar, Dennis Jones, Dick Sandberg

\title{
Wood modification technologies - a review
}

\author{
Dick Sandberg ${ }^{(1)}$, \\ Andreja Kutnar ${ }^{(2-3)}$, \\ George Mantanis ${ }^{(4)}$
}

\begin{abstract}
The market for new durable products of modified wood has increased substantially during the last few years, especially in Europe. This increased interest depends partly on the restricted use of toxic preservatives due to increased environmental concern, as well as the need for reduced maintenance for wood products that are mainly for exterior use. Furthermore, as sustainability becomes a greater concern, the environmental impact of construction and interior materials should be included in planning by considering the entire life cycle and embodied energy of the materials used. As a result, wood modification has been implemented to improve the intrinsic properties of wood, widen the range of sawn timber applications, and acquire the form and functionality desired by engineers, without bringing environmental friendliness into question. The different wood modification processes are at various stages of development, and the challenges that must be overcome to expand to industrial applications differ amongst them. In this paper, three groups of wood modification processes are discussed and exemplified with modified wood products that have been newly introduced to the market: (i) chemical processing (acetylation, furfurylation, resin impregnation etc.); (ii) thermo-hydro processing (thermal treatment); and (iii) thermo-hydro-mechanical processing (surface densification). Building on these examples, the paper will discuss the environmental impact assessment of modification processes and further development needs.
\end{abstract}

Keywords: Chemical Treatments, Thermo-hydro-mechanical, LCA, Acetylation, Furfurylation, Resin Impregnation, Environmental Impacts, Densification

functionality. Modification is applied to overcome weak points of the wood material that are mainly related to moisture sensitiveness, low dimensional stability, hardness and wear resistance, low resistance to bio-deterioration against fungi, termites, marine borers, and low resistance to UV irradiation.

Nowadays, wood modification is referred to as a process used to improve the physical, mechanical, or aesthetic properties of sawn timber, veneer or wood particles used in the production of wood composites. This process produces a material that can be disposed at the end of a product's
(1) Luleå University of Technology, Wood Science and Engineering, SE-931 87 Skellefteå (Sweden); (2) University of Primorska, Andrej Marušič Institute, Muzejski trg 2, SI-6000 Koper (Slovenia); (3) InnoRenew CoE, Livade 6, SI-6310 Izola (Slovenia); (4) TEI of Thessaly, Research Lab of Wood Science and Technology, Griva 11, GR-43100 Karditsa (Greece)

@ Dick Sandberg (dick.sandberg@ltu.se)

Received: Jan 30, 2017 - Accepted: Aug 13, 2017

Citation: Sandberg D, Kutnar A, Mantanis G (2017). Wood modification technologies - a review. iForest 10: 895-908. - doi: 10.3832/ifor2380-010 [online 2017-12-01]

Communicated by: Giacomo Goli life cycle without presenting any environmental hazards greater than those that are associated with the disposal of unmodified wood.

The wood modification industry is currently undergoing major developments, driven in part by environmental concerns regarding the use of wood treated with certain classes of preservatives. Several "new" technologies, such as thermal modification, acetylation, furfurylation, and different impregnation processes, have been successfully introduced in the market and demonstrate the potential of these modern technologies.

The main reasons for the increased interest during the last decades in wood modification with regard to research, the industry, and society in general can be summarised as:

- a change in wood properties as a result of changes in silvicultural practices and the way of using wood (e.g., in construction); - awareness of the use of rare species with outstanding properties, such as durability and appearance;

- awareness and restrictions by law of using environmental non-friendly chemicals for increased durability and reduced maintenance of wood products;

- increased interest from the industry to 


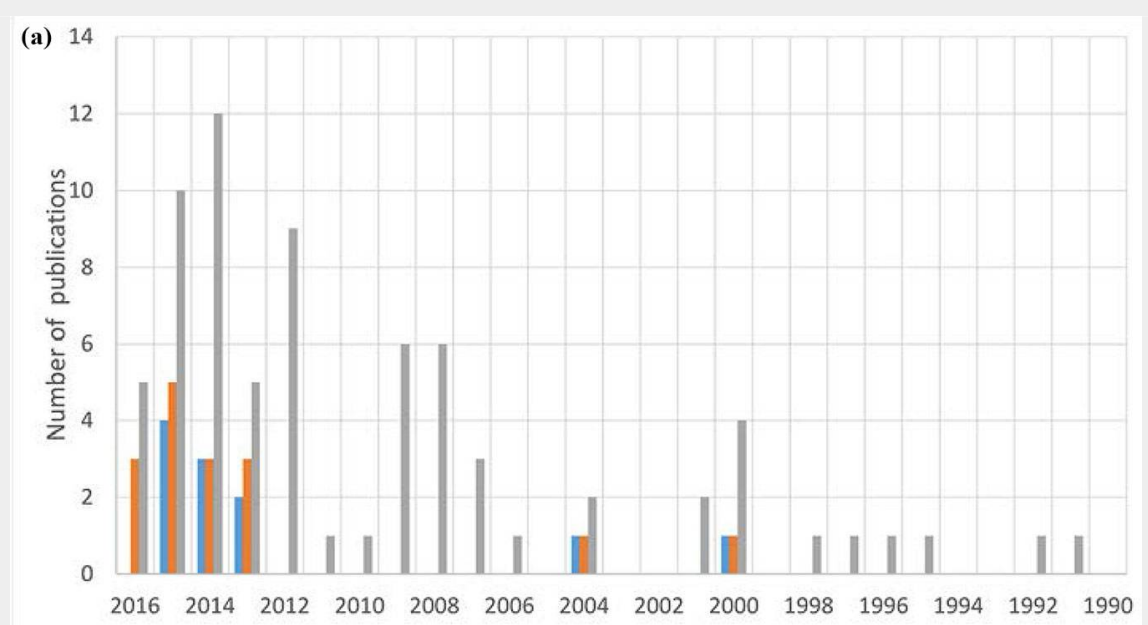

피 Thermo-hydro-mechanical treatment AND wood 푸 Thermo-hydro treatment AND wood = Thermo-mechanical treatment AND wood

(b) 300

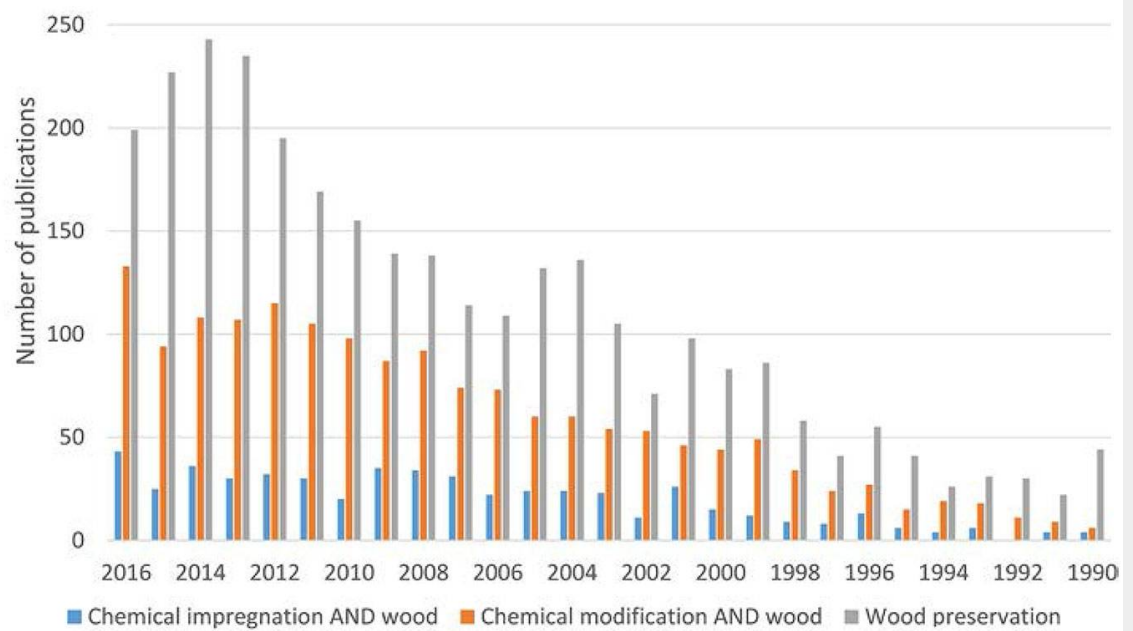

(c) 100

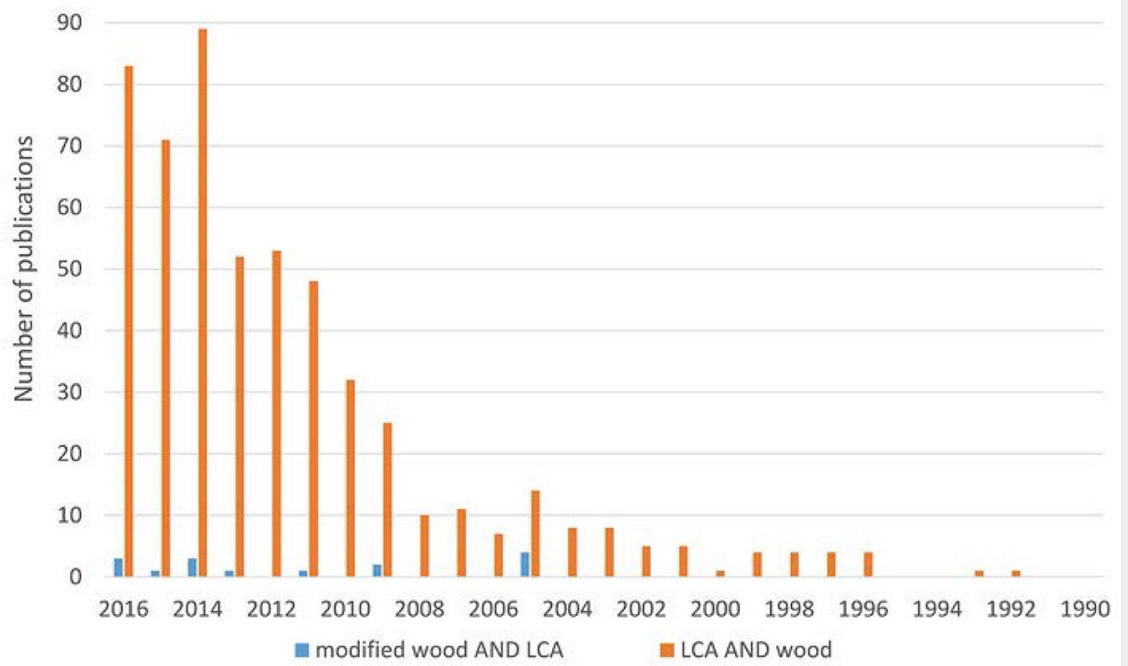

Fig. 1 - Number of publications found in the Scopus ${ }^{\circledast}$ database of peer-reviewed articles 1990-2016 using keywords related to: (a) thermo-based modification methods; (b) chemical modification methods; and (c) "modified wood" and "LCA", and "LCA" and "wood".

add value to sawn timber and by-products, from the sawmill and refining processes;
- EU policies supporting the development of a sustainable society; and

- the international dimension on climate change and related activities mainly organised within the frame of the United Nations (UN), such as the Paris Agreement under the United Nations Framework Convention on Climate Change (United Nations 2015).

The purpose of this review is to present state-of-the-art wood modification processes recently introduced in European market with a specific focus on chemical processing (acetylation, furfurylation, impregnation modifications) and thermo-hydro and thermo-hydro-mechanical processing (thermal treatment, surface densification). Continuous surface densification is given as an example of a modification process that has been under development for a long time, but is now close to industrial application. The importance of integrating environmental impact assessments into the optimisation of industrial processes and the development of new modification processes is discussed. The dynamics of the research interest these modification treatments have received is presented with an overview of the number of publications published in the field during the period 1990-2016.

\section{Wood modification in scientific publications}

Scientific articles related to wood modification have been increasing over the past decade. Fig. 1a-b search amongst article titles, abstracts, and keywords in the Scopus ${ }^{\circledast}$ database of peer-reviewed literature using keywords related to thermal-based modification and chemical modification. While the increased number of articles indicate the development of wood modification in general, chemical modification of wood has been studied more frequently in recent years, showing nearly 50 times more articles than thermal-based modification. Furthermore, about half of the chemical modification articles are related to wood preservation.

This review of the Scopus ${ }^{\circledast}$ database shows that wood modification area is receiving an increased interest in the scientific community, much of which has been driven by environmental concerns and increased wood use in novel applications to replace fossil-based materials. However, it is important that environmental impact assessments, such as life cycle assessments (LCAs) of wood products, especially of modified wood, are included in the development of new treatments, wood-based materials, and products. Fig. $1 \mathrm{c}$ shows the number of articles using keywords related to modified wood and LCA. Increased involvement of LCA in research has been the consequence of standardised requirements and guidelines for LCA. In the entire search time frame, there were only 15 publications that included the keywords "modified wood" and "LCA". To optimise modification processing and minimise environmental impacts, more information must be gathered about all process-related factors 
affecting the environment. This is also the aim of COST Action FP1407 "Understanding wood modification through an integrated scientific and environmental impact approach", in which members from 26 European countries participating from March 2015 to April 2019. The initiative will facilitate the critical mass of Europe-wide knowledge needed to achieve future developments in the wood modification processing with the integration of process parameters assessments, developed product properties, and environmental impacts.

\section{Wood modification}

Wood modification is an all-encompassing term to describe the application of chemical, mechanical, physical, or biological methods to alter the properties of the material. Such a definition of wood modification includes almost everything that happens within the wood material after it has left the forest. Hill (2006) has provided a well-accepted definition of wood modification: "Wood modification involves the action of a chemical, biological or physical agent upon the material, resulting in a desired property enhancement during the service life of the modified wood. The modified wood should itself be nontoxic under service conditions, and furthermore, there should be no release of any toxic substances during service, or at end of life, following disposal or recycling of the modified wood. If the modification is intended for improved resistance to biological attack, then the mode of action should be non-biocidal". It should be noted that the above does not necessarily exclude the use of a hazardous chemical in the preparation of modified wood, provided that no hazardous residues remain once the wood modification process is complete.

To modify wood, four main types of processes can be implemented: (1) chemical treatments; (2) thermo-hydro (TH) and thermo-hydro-mechanical (THM) treatments; (3) treatments based on biological processes; and (4) physical treatment with the use of electromagnetic irradiation or plasma. In this review paper, only the two first processes will be discussed.

While chemical treatments are the most numerous type of processes, and the range of chemical agents is extremely broad, only heat and water are used during $\mathrm{TH}$ and THM treatments, albeit supplemented with mechanical forces in the latter case.

\section{Principal mechanisms of wood modification}

Modification of wood can involve active modifications, which result in a change of the chemical nature of the material, or a passive modification, in which a change in properties results without altering the chemistry of the material. Most active modification methods investigated to date have involved the chemical reaction of a reagent with cell-wall polymer hydroxyl groups. These hydroxyl groups play a key

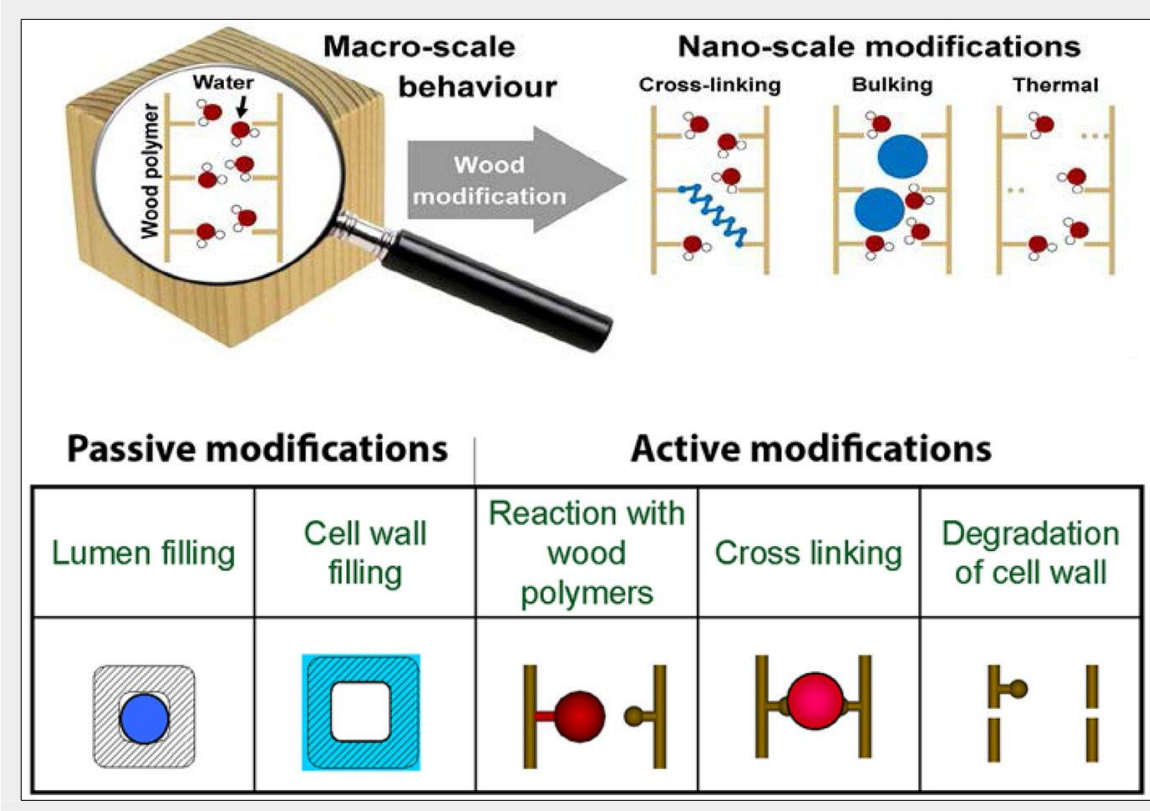

Fig. 2 - Schematic diagram illustrating the effect of chemical modification (courtesy: Emil Engelund Thybring, University of Copenhagen, Denmark).

role in the wood-water interaction while simultaneously being the most reactive sites (Fig. 2). In moist wood, the water molecules settle between the wood polymers, forming hydrogen bonds between the hydroxyl groups and individual water molecules. A change in the number of these water molecules results in shrinkage and swelling of the wood. All possible types of wood treatments affect the wood-water interaction mechanism. The main woodtreatment interaction mechanisms that may be responsible for new wood properties are summarised in Fig. 2.

Several wood-treatment interaction mechanisms tend to occur at the same time. In thermal modification, as one example, parts of the cell-wall polymers are altered, which may lead to cross-linking, reduction of $\mathrm{OH}$-groups, and undesired cleavage of the polymer chains.

It should be noted that most of the wood modification processes that are developed or under experimentation have full or partial origins in the pioneering research and seminal work of Alfred J. Stamm and his colleagues at the Forest Products Laboratory in Madison, Wisconsin, during the 1940 s and 1950 s.

\section{Chemical wood modification processes}

Chemical modification of wood takes place when a chemical reaction of an agent occurs with the polymeric constituents of wood (lignin, hemicelluloses, or cellulose), thus resulting in the formation of a stable covalent bond between the reagent and the cell-wall polymers (Rowell 1983).

Consequently, chemical modification of wood is considered as an active modification because it results in a chemical change in the cell-wall polymers. Much is known about the modes of action of modified wood, which incorporates a combination of the following: (i) the equilibrium moisture content is lowered in modified wood, and it is harder for fungi to obtain the moisture required for decay; (ii) a physical blocking of the entrance of decay fungi from the micro pores of the cell walls; and/or (iii) inhibition of the action of specific enzymes (Hill 2006, 2009, Rowell et al. 2009, Rowell 2016). To date, these are the three most important aspects of the entire mechanism that have been speculated.

Impregnation modification of wood is another type of modification. It implies that there is an impregnation of the cell wall of wood with a chemical, or a combination of chemicals, that reacts to form a material that is "locked" into the cell wall (Hill 2006). It is a passive modification process, meaning that although the wood properties are affected, there is no alteration in the chemistry of the material. This type of wood modification includes either impregnation of the cell wall with a monomer, which is subsequently polymerised in situ, i.e., acts by bulking the cell wall, or the lumens being impregnated. While the latter does not affect the dimensional stability or durability, the impregnant molecules must be small enough to enter the cell wall in the former, i.e., the cell wall micropore diameter should be approximately 2-4 $\mathrm{nm}$. The most important chemical processes of wood modification are discussed as follows.

\section{Acetylation}

In Germany, Fuchs (1928) carried out the first experiment on wood acetylation using chemical agents like acetic anhydride and sulphuric acid as catalysts. Tarkow (1946) was the first researcher who described the use of the acetylation process to stabilise wood from swelling in the water. Since the 
1940s, many laboratories worldwide have executed studies on the acetylation of wood in a variety of ways by using several wood species (Rowell 1983). However, early attempts proposed by Koppers Inc. in 1961 to commercialise the process of wood acetylation in the USA failed due to the high production costs involved (Rowell 2012, 2016). Innovative laboratory work to extend acetylation to the semi-industrial level was successfully performed at Stichting Hout Research in the Netherlands by Militz and his colleagues during the 1990s (Militz 1991, Beckers et al. 1994, Homan 2008).

Wood acetylation using primarily acetic anhydride was first generated as a liquid phase reaction (Rowell 1983). This work was initiated using acetic anhydride catalysed by zinc chloride or pyridine. Since then, several other catalysts, including sodium acetate, potassium acid, urea-ammonium sulphate, have been tested both with liquid and vapour systems (Rowell 1983, Hill 2006). Most acetylation reactions today are realised without the use of a catalyst (Larsson-Brelid 2013, Rowell 2016, Mantanis 2017).

The reaction of acetic anhydride with wood polymers results in the esterification of accessible hydroxyl groups in the cell wall with the formation of a by-product, acetic acid (Fig. 3). This by-product is mostly removed from the modified wood, as the human nose is quite sensitive to the odour of acetic acid. Like untreated wood, acetylated wood is comprised only of carbon, hydrogen, and oxygen, and contains no toxic constituents (Hill 2006). Furthermore, acetylation of wood is a single-addition chemical reaction (Rowell 1983), which means that one acetyl group reacts with one hydroxyl group without any polymerisation (Fig. 3).

Many scientists today believe that wood acetylation reduces the number of hydroxyl groups $(-\mathrm{OH})$ that can absorb moisture by hydrogen bonding to largely reduce the equilibrium moisture content and fibre saturation point. Hence, the dimensional stabilisation of wood improves with increasing weight gain, due to acetylation reaction (Rowell et al. 1994, 2009, Larsson-Brelid 2013, Rowell 2016). Other scientists favour another mechanism: by modifying wood with acetic anhydride, it is observed that the dimensional stabilisation is closely related to the weight percentage gain (WPG) or bulking of the cell wall. As a conse- quence, the extent of $\mathrm{OH}$-substitution is rather irrelevant (Papadopoulos \& Hill 2002, Hill 2006, Jones \& Hill 2007, Papadopoulos 2010).

As far as biological resistance is concerned, several theories have been proposed to explain the high resistance of acetylated wood to fungal attacks. One theory that has gained large acceptance, is that enzyme penetration is prevented by physically blocking the cell-wall micropores (Papadopoulos \& Hill 2002, Hill 2006, 2009). In agreement with the above, Highley et al. (1994) showed that the smallest enzyme of a brown-rot fungus is too large to penetrate the cell wall of wood.

On the contrary, Rowell has postulated that the mechanism of decay resistance in acetylated wood is based on "moisture exclusion", the equilibrium moisture content of a highly modified wood is too low to support fungal attacks, i.e., there are not enough water molecules at the site of a glycosidic bond, which the fungal enzymes need for hydrolysis (Rowell 1983, Rowell et al. 2009). In a recent review by Rowell (2014), supported the idea that in the case of a brown-rot fungal attack, the reduced moisture of acetylated wood prevents the fungus from initiating the breakdown of the hemicelluloses as an energy source.

In his doctorate work, Mohebby \& Militz (2010) speculated a third possible mechanism: some minuscule regions in the cell wall are not acetylated, due to the size of the acetate group itself. As a result, these regions are accessible to the free radicals generated by the fungi. In another review, Hill (2009) concluded that the substrate recognition effects were unlikely to be of importance, given the inherent lack of enzyme accessibility. Therefore, the reduced cell-wall water content was considered to be the most likely mechanism for the high biological resistance of acetylated wood.

However, recent research works (Alfredsen et al. 2015, Ringman et al. 2015) have demonstrated that the mechanism of substrate recognition by the fungus should be considered as critical, in combination with the lowered moisture content as distributed within the wood matrix.

Nowadays, the company Accsys Technologies in Arnhem (The Netherlands) industrially produces acetylated wood. This wood material is marketed under the commercial name Accoya ${ }^{\oplus}$; the radiata pine ( $P$ inus radiata) and alder (Alnus spp.) species are currently utilised. On average, Accoya

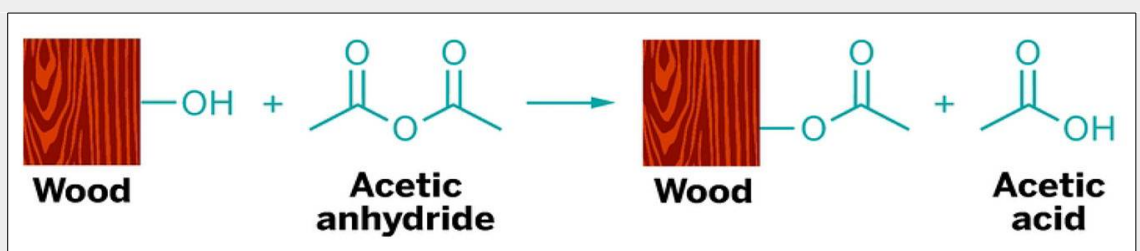

Fig. 3 - The main reaction of wood acetylation with acetic anhydride. wood attains an acetyl weight gain of approximately $20 \%$. About $40,000 \mathrm{~m}^{3}$ acetylated wood was produced by the company Accsys in the year 2016, and the company plans to raise its present capacity to ca. $60,000 \mathrm{~m}^{3}$ in 2018 (Mantanis 2017). The main uses of Accoya wood include: exterior windows and doors, decking, cladding, and other civil construction applications (Rowell 2016).

The acetylation process currently applied by Accsys Technologies yields chemically modified timber, which has largely improved physical, mechanical, and biological material properties (Hill 2006, Jones \& Hill 2007, Rowell et al. 2009, Larsson-Brelid 2013, Alexander et al. 2014, Gérardin 2016, Rowell 2016), which are discussed as follows:

- The biological durability of wood has been improved to the highest durability class (Class 1), similar to the extremely durable tropical species teak (Tectona grandis) and ipé (Handroanthus spp.). Acetylated wood material exhibits a considerably increased biological resistance (Larsson-Brelid et al. 2000, Papadopoulos \& Hill 2002, Mohebby \& Militz 2010, Rowell 2012, Larsson-Brelid 2013).

- Acetylated wood has a fibre saturation point below $15 \%$, and the cell wall attains a high moisture exclusion efficiency (Hill 2006). Consequently, the swelling and shrinkage properties are reduced by 70 $80 \%$, as compared to untreated wood (Jones \& Hill 2007, Rowell 2012). The reason for that is simply because the cell wall is filled with chemically bonded acetyl groups, which utilise space within the cell wall (Hill 2006) denying space to water molecules.

- Acetylated wood has been proven to be exceptionally resistant to subterranean and Formosan termites (Alexander et al. 2014).

- At treatment levels $>20 \%$ (acetyl content), Accoya wood has been found to possess excellent resistance to marine borer attacks even after 16 years of field exposure in the same or better order than CCA treated pine wood (Westin et al. 2016).

- Acetylated wood can become 15-30\% harder than untreated wood (Rowell 2012).

- Acetylation technology has negligible impacts on the mechanical (strength) properties of wood material (Rowell 2012, Larsson-Brelid 2013).

- Acetylated wood is marketed today as a "green" product with several environmental benefits (Jones \& Hill 2007, Lande et al. 2008, Van Der Lugt et al. 2016). According to Van Der Lugt et al. (2016), acetylated wood demonstrates a much lower carbon footprint than steel, concrete, and unsustainably sourced azobé (Lophira alata). As a result, Accoya wood has showed $\mathrm{CO}_{2}$-negative life-cycle-analysis (LCA) results over an entire life cycle.

Due to the listed advantages of the material, Accoya wood has the potential to be 
widely used in certain applications. In Germany, Accoya wood, as a new wood material, has recently gained acceptance for use in exterior windows, by the German association of Windows and Facades (VFF). However, a limitation is that only radiata pine (Pinus radiata) and alder (Alnus spp.) are currently used in the process (Mantanis 2017), and there is a need to widen the number of wood species that can be utilised.

\section{Furfurylation}

Research relating to chemical modification of wood with furfuryl alcohol $\left(\mathrm{C}_{5} \mathrm{H}_{6} \mathrm{O}_{2}\right)$ was initiated by the renowned researchers A. Stamm and I. Goldstein (Goldstein 1959, Stamm 1977). By using cyclic carboxylic anhydrides as key catalysts, furfurylated wood with superior properties better than those produced with the early developed systems was achieved by Scheider (1995) in Canada. Innovative research work was also carried out by Westin and his collegues (Westin et al. 1998) in Sweden, which led to a novel technology based on stable solutions with substantial impregnating capacities and promising properties, like resistance to decay.

Furfuryl alcohol is a liquid produced from agricultural wastes, such as sugar cane, and corn cobs. Furfurylation is executed by impregnating wood with a mixture of furfuryl alcohol and catalysts, and then heating it to cause polymerisation. The purpose of furfurylation is to improve resistance to biological degradation and dimensional stability by applying a non-toxic, proprietary, furfuryl alcohol polymer.

The polymerisation of furfuryl alcohol in wood is a complex chemical reaction. Even today, the question of whether furfurylation is a distinct chemical modification process remains unanswered. Some scientists believe that it comprises a chemical modification process, since the furfuryl alcohol polymer reacts with itself and possibly reacts with the lignin in the cell walls (Lande et al. 2008, Nordstierna et al. 2008, Gérardin 2016, Li et al. 2016). Thus, the furfuryl alcohol complexes are predominantly deposited in the wood cavities and cell walls (Fig. 4). Polymerisation takes place in microscopic cell cavities and is easily detected using optical microscopy. Recent nanoindentation studies have indicated that improvements in indentation modulus and hardness of furfurylated wood cells demonstrate indirectly, but strongly, that furfuryl alcohol penetrates wood cells during the modification process ( Li et al. 2016). Another perception is that furfurylation leads to a permanent "bulking" of the cell wall, meaning that the cells are swollen in a permanent way. One possible explanation is that the furfuryl alcohol polymer inside the cell wall occupies some of the space that is normally filled with water molecules when wood swell in humid conditions (Lande et al. 2008). Various scientists consider wood furfurylation as an impregna-

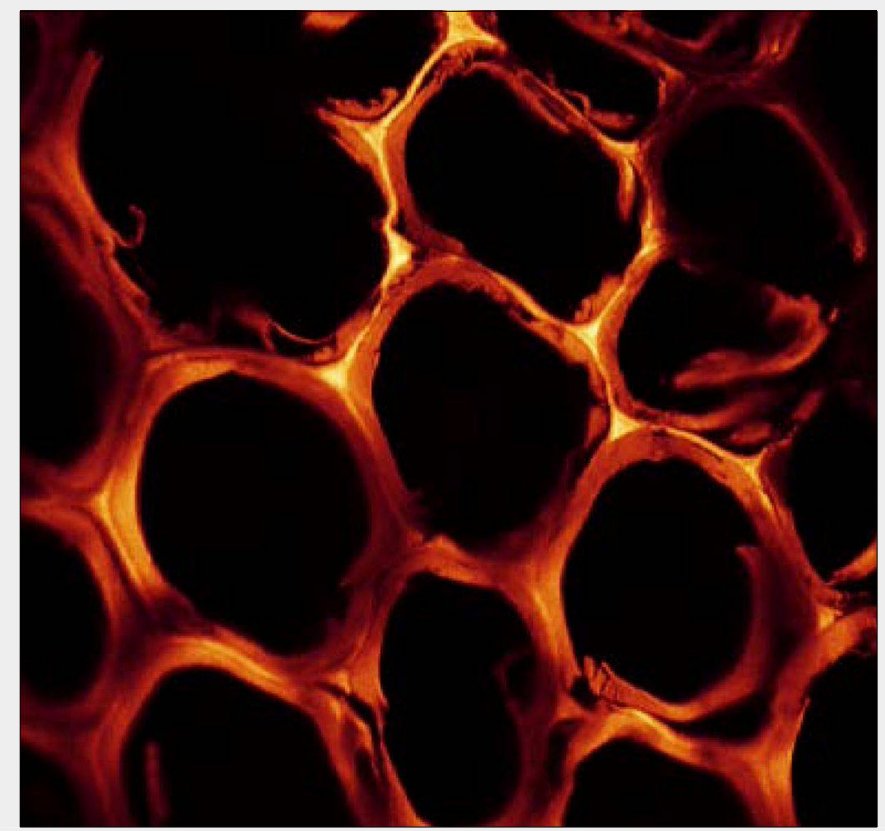

Fig. 4 - Cross section of radiata pine wood with cell walls containing furan polymer (in reddish areas), image through fluorescence microscopy (Thygesen et al. 2010).

tion modification process, in which the properties of the furfurylated material appear more like those of a polymer-filled cell wall rather than a reacted cell wall (Rowell 2012, Larsson-Brelid 2013).

Nowadays, the industrial production of furfurylated wood is carried out by Kebony AS (formerly Wood Polymer Technologies) in Norway. According to Lande et al. (2004), the industrial process of wood furfurylation is comprised of the following:

- Storage and mixing of chemicals: the treating solutions are mixed in a separate mixing tank where different chemicals (furfuryl alcohol, initiators/catalysts, buffering agents, surfactants, water) are added. The mixed solution is pumped to one of the buffer tanks.

- Impregnation: the wooden material, i.e., treatable softwoods or hardwoods, is vacuum pressure impregnated with the treating solution by a full-cell process with a vacuum step, a pressure step, and a short post-vacuum step.

- Reaction and curing: in-situ polymerisation of the chemicals and grafting reactions with the polymeric components of the wood occur during this step. The curing chamber is heated with a direct injection of steam, and the temperature achieved depends on the product use. The chamber is operated as a closed system during the curing period, except for a ventilation period at the end. The ventilation gas is cooled and the condensate is separated from the gas; thereafter, the condensate goes back to the condensate tank for re-use.

- Drying: final drying of the modified wood material in a kiln dryer is essential to minimise emissions and obtain a desirable final moisture content.

- Cleaning: the emissions during the process are managed by cleaning the ventilated gases.
According to the literature (Lande et al. 2004, 2008, Lande 2008, Rowell 2012, Larsson-Brelid 2013, Mantanis \& Lykidis 2015), the furfurylation process results in a modified wood product that has distinctly improved properties, which are summarised as follows:

- The biological durability of wood is upgraded to "Class 1" (Gérardin 2016). Decay resistance test results over a period of 9 years have showed that furfurylated wood of moderate loading (30-35\% of weight percentage gain) has comparable resistance with that of pine wood impregnated with copper chromium arsenate (Larsson-Brelid 2013).

- The mechanical properties of wood, except for impact resistance, are enhanced when wood is treated with a furfuryl-alcohol polymer. Furfurylated wood is characterised by greater hardness, elasticity, and rupture moduli as compared to untreated wood; however, it is also more brittle (Larsson-Brelid 2013).

- Kebony wood, depending upon the loading, exhibits strong dimensional stability and resistance to weathering (Mantanis \& Lykidis 2015); moreover, its water swelling and shrinking values are over 50\% lower than untreated wood.

- Furfurylated wood is extremely resistant to marine borers at high levels $(>50 \%)$ of weight percentage gain (Westin et al. 2016).

- Recent studies regarding ecotoxicology of furfurylated wood and leachates from furfurylated wood showed no significant ecotoxicity, while its combustion did not release any volatile organic compounds or polyaromatic hydrocarbons above the normal levels of wood combustion (Pilgård et al. 2010).

- Furfurylated wood is a "green" wood product that holds an ecological label in the Scandinavian market, named "Swan". 
Furfurylation of wood is, therefore, believed to be a safe process for the environment (Gérardin 2016).

The company Kebony AS (Norway) currently produces two different furfurylated wood products:

- Kebony Clear $^{\oplus}$ : furfurylated wood, highlyloaded, dark, hard; currently used for flooring. The wood species used are radiata pine, southern yellow pine and maple. - Kebony Character ${ }^{\oplus}$ : furfurylated wood, more lightly-loaded; presently used as decking, siding, roofing and outdoor furniture. This is produced from Scots pine wood.

Nowadays, the company Kebony AS has an annual production of approximately $22,000 \mathrm{~m}^{3}$ (2016), and it is increasing its production capacity by building additional facilities in Belgium (Mantanis 2017).

In addition, Kebony wood has been recently used in the production of exterior windows, like Accoya wood. Following a series of extensive quality tests in Germany, furfurylated wood is presently rec ommended by the German Association of Windows and Facades (VFF).

\section{Modification with thermosetting resins}

Historically, the first experiments on impregnation modification of wood using formaldehyde-based resins were carried out by A. Stamm and his colleagues at the Forest Products Laboratory in Madison, Wisconsin, during the 1940s. Their initial research work included impregnation of wood with phenol-formaldehyde resins with up to $100 \%$ resin addition, which resulted in an improved dimensional stability (anti-shrink efficiency, ASE, up to 58\%) and improved resistance to biodeterioration against fungi, termites, and marine borers. Initial experiments using wood veneers by applying impregnation with phenol-formaldehyde (PF) resins, heat, and compression were implemented by Stamm \& Seborg (1955), leading to the production of products called Compreg ${ }^{\oplus}$ and Impreg ${ }^{\oplus}$.

Compreg manufacturing is currently realised at a number of industrial sites in the USA, Pakistan, and India under different brand names. Compreg and related products (Fibron, Permali, Dymonwood, C-K Composites) have potent dimensional stability and high strength properties, like hardness, abrasion resistance, and compression strength (Hill 2006). Products resulting from these impregnation treatments have been used in the manufacturing of knife and tool handles, and musical and electrical instruments, but not directly for preservation purposes (Gérardin 2016). The volumes of these products are currently very low (Hill 2006).

Research on the impregnation modification of wood with melamine-formaldehyde (MF) resins has increased in recent decades, especially in Europe, with positive results with respect to dimensional stability and biological resistance to brown-rot fungi (Inoue et al. 1993, Pittman et al. 1994, Rapp \& Peek 1999, Lukowsky 1999, Gindl et al. 2003, Kielmann et al. 2012, Sint et al. 2013, Kielmann et al. 2014). Its main drawbacks are the high production costs and the tendency of such wood products to crack under humid-dry cycle conditions. None of these impregnation modification methods have yet to reach the full-scale level.

\section{Modification with DMDHEU}

This technology was transferred from the treatment of non-wood systems. Furthermore, it involves the impregnation of pine wood, a known highly porous species, with the reagent 1,3-dimethylol-4,5-dihydroxyethyleneurea (DMDHEU). This reagent (Fig. 5) was well-utilised in the textile industry until the 1980s, in an attempt to manufacture wrinkle-free fabrics. Wood modification with DMDHEU has been shown to improve dimensional stability and durability, and to slightly reduce the moisture uptake of wood (Nicholas \& Williams 1987).

Militz (1993) was the first scientist to successfully report on the use of DMDHEU in treating wood, with very positive results. Militz tested beech wood treated with DMDHEU and demonstrated its effectiveness by using a variety of catalysts. It was finally found that temperatures of $100{ }^{\circ} \mathrm{C}$ were necessary for the effective curing of the resin system. Noticeably, the antishrink efficiency (ASE) value of DMDHEUtreated wood was found to be ca. $75 \%$.

Since then, the process has undertaken considerable improvements by Militz and co-workers (Krause et al. 2003), from which commercial application has been fi-
Fig. 5 - The chemical formula of the reagent $1,3-\mathrm{di}-$ methylol-4,5-dihydroxyethyleneurea (DMDHEU)

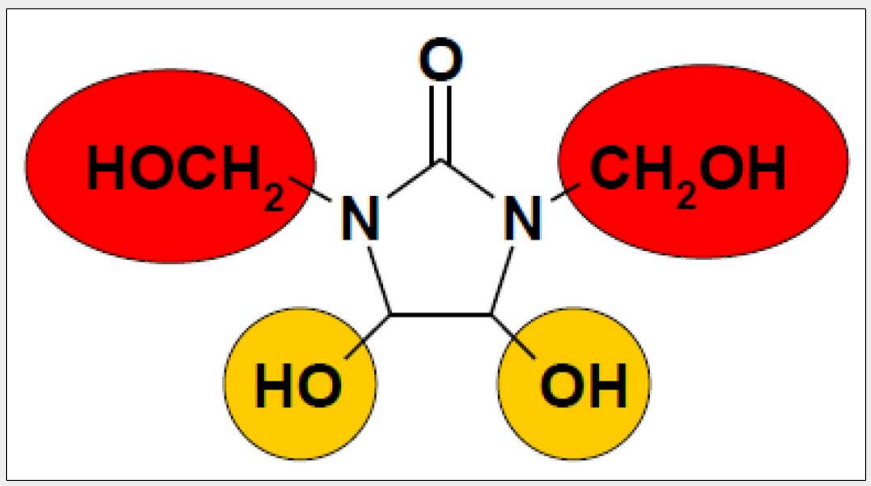

nally achieved in Germany. This impregnation modification process is presently marketed by the German company BASF under the commercial name Belmadur ${ }^{\oplus}$.

This technology is considered to be an innovative modification process under which pine wood, typically Scots pine, is impregnated under high pressure (12-14 atm) and polymerised by curing. The entire process is based on simple production stages. The first stage consists of penetrating the wood with a proprietary DMDHEU solution, an aqueous solution of a chemical agent (Militz 1993). The air is removed from the cell structure by applying a vacuum to ensure that the agent can reach the innermost cells when the solution is applied under pressure. The next stage consists of drying impregnated wood at a slow rate at a temperature of $100-120{ }^{\circ} \mathrm{C}$ under humid conditions. This causes the agent molecules to cure by polycondensation, after which water is released (Krause et al. 2003, Krause \& Militz 2009).

The modified product has highly reduced hygroscopic properties (Krause \& Militz 2009, Papadopoulos \& Mantanis 2012, Larsson-Brelid 2013). ASE values of up to $70 \%$ can be achieved (Krause \& Militz 2009), but are normally in the range of $30-40 \%$ (Krause et al. 2003). The mechanisms of the reaction between DMDHEU and the cell wall polymers are still not clear (Hill 2006, Larsson-Brelid 2013). It has been shown that the modification of wood with DMDHEU produces a bulking effect, while results from Dieste et al. (2009) have indicated that DMDHEU reduces the pore size of the samples by occupying the void space present in the cell walls.

Belmadur wood production is still sparse in Germany. The producing German company, Münchinger, belongs to the BASF group; and to date, it is focusing on the German market. Key applications thus far have been decking and garden furniture. However, a laminated Belmadur product has gained acceptance by the German association of Windows and Facades (VFF) for use in exterior windows. The resistance of Belmadur wood to marine borers is substantial (Larsson-Brelid 2013). However, the drawbacks are brittleness, tendency to crack, and high emissions of formaldehyde from the product. In addition, the present technical and market developments of Belmadur technology are not known.

\section{The Indurite process}

The "Indurite process" has been developed from a comprehensive survey of possible reactions of wood cell walls with polymer systems. The technology was scaledup by the company Engineered Wood Solutions in New Zealand (Hill 2006), after which it was obtained by the company Osmose. The original concept for Indurite was undertaken to upgrade home-grown radiata pine (Pinus radiata) by impregnation of wood with a water-soluble polysaccharide solution (soy and corn starch). The 
Fig. 6 - Classification of thermo-hydro (TH) and thermo-hydro-mechanical (THM) processes (Sandberg \& Kutnar 2016).

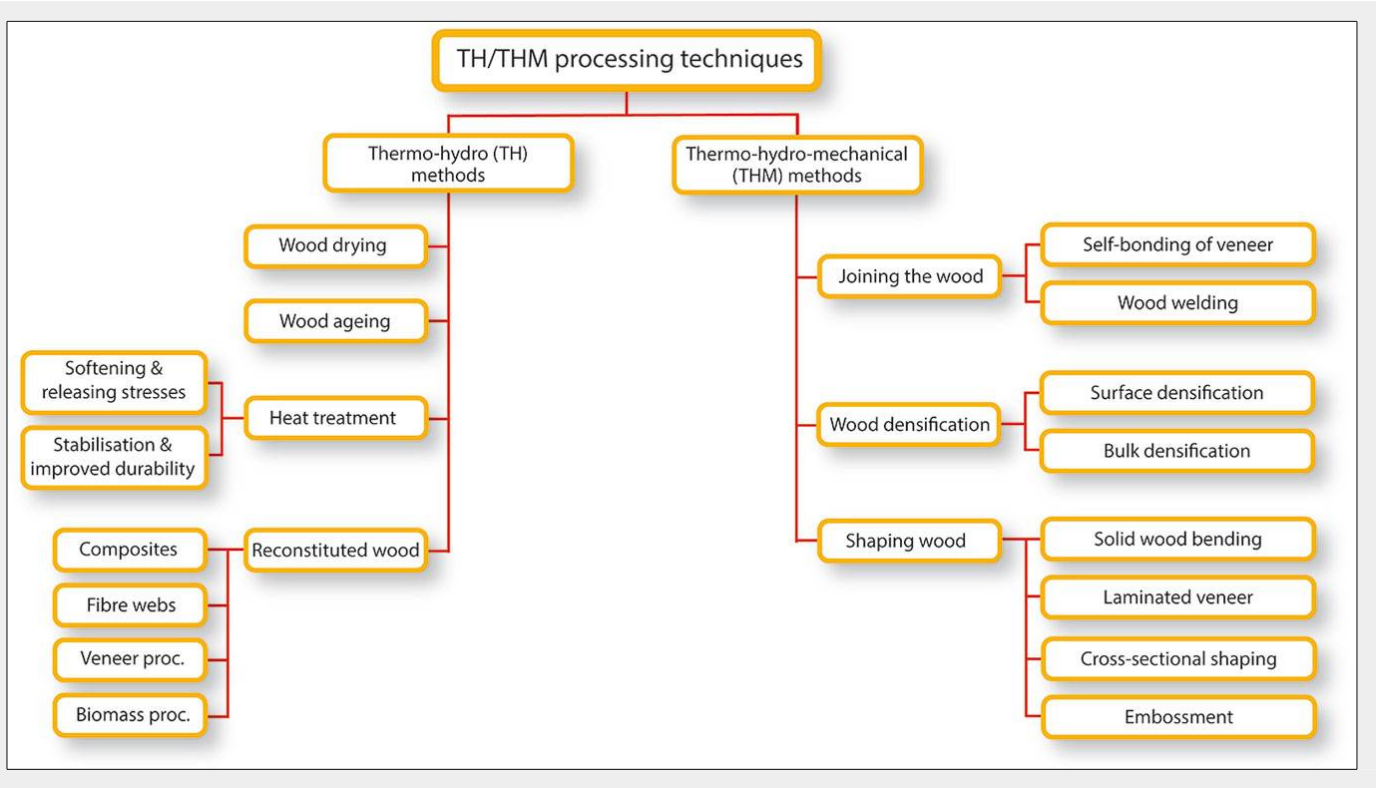

impregnated material is held in a covered area for a few hours, and then the curing step takes place in a temperature-controlled conventional kiln with the use of certain catalysts in the solution (Hill 2006). A major advantage is that there is no need for significant equipment investments. This modified wood is claimed to be used presently in exterior applications such as cladding and decking. However, the present developments of this technology are not clear.

\section{The KeyWood process}

According to Larsson-Brelid (2013), a new product named KeyWood ${ }^{\circledast}$, which resembles furfurylated wood, was developed within the EU-funded project "Ecobinders". The reactant, which contains small amounts of tri-hydroxy-methyl furan (THMF) and furfuryl alcohol, is more water soluble than furfuryl alcohol itself, and easily penetrates the cell wall. After curing the THMF-impregnated wood, the polymer formed within the cell wall resembles the polymer formed by the Kebony process. However, unlike furfurylated wood, no covalent bonds to the cell wall polymeric constituents (lignin, hemicelluloses, cellulose) were detected in the analytical studies within the "Ecobinders" project. Furthermore, due to the higher quantity of remaining hydroxyls in the polymer as well as the lack of bonds to the lignin, the KeyWood product has a higher equilibrium moisture contents than furfurylated wood at the same level of relative humidity. Furthermore, kiln drying temperatures of $125{ }^{\circ} \mathrm{C}$ are necessary for sufficient curing; consequently, this temperature causes problems with cracking and brittleness. While the technology was sold to the company Arch SA in 2009, the production volumes seem to be very small. Meanwhile, the present market developments of the KeyWood process are not clear and have not been disclosed publicly.

\section{Modification processes using monomers}

Vinyl monomer impregnation of wood, followed by in situ polymerisation, represents another promising way to enhance mechanical, dimensional, and thermal stability, as well as fungal and insect resistance to wood species of poor natural durability. Different commercially available vinyl monomers, such as acrylonitrile, glycidyl methacrylate, methyl methacrylate, hydroxyethylene methacrylate, ethylene glycol, dimethacrylate, butyl acrylate, butyl methacrylate, styrene, acrylamide or acrylonitrile, have been investigated by several scientists (Hill 2006, Rowell 2012).

According to the nature of the monomer used, polymerisation can take place either in the cell lumens, the cell wall, or both (Scheider 1995). Polymerisation can be initiated by different means using either thermal-free radical initiator, or gamma radiation. X-rays, derived from a high-energy, high current electron beam, can be also used to initiate in situ polymerisation of vinyl monomers. X-rays initiate polymerisation and penetrate through thick pieces of wood, allowing polymerisation of the monomers in the cell walls. Having entered the cell walls and then being polymerised within the cell walls, these radiation-cured treatments increased the dimensional stability of treated wood (Gérardin 2016). Nevertheless, all the abovementioned techniques have not resulted in commercial applications to date.

\section{Thermo-hydro and thermo-hydro- mechanical processes}

One group of emerging wood treatments involves the combined use of temperature and moisture through which force can be applied: thermo-hydro ( $\mathrm{TH}$ ) and thermo-hydro-mechanical (THM) processes. In an orthodox definition, no additives are used in the processes beyond water in combination with wood, heat, and external forces to shape the wood. Procedures including impregnation or gluing to lock a shape are, however, usually included in these modification processes.

Human beings have demonstrably been using heat, moisture, and force for the modification of wood since ancient times; it can be assumed that they had long recognised the effects of fire and water on timber, utilising them for their own purposes (Navi \& Sandberg 2012, Sandberg et al. 2013). The oldest evidence on THM processing is a heat-hardened tip of a more than 100,000-year-old Lehringen spear found in 1948, buried inside the skeleton of an elephant (Adam 1951). Nevertheless, it was not until the $19^{\text {th }}$ century that the use of water and heat in wood processing was industrialised. In 1849, the inventor of the Vienna Chair and the technology related to its production, Michael Thonét, started a workshop for the production of bent wood furniture. Thonét's innovations were the first steps towards the industrialisation of a $\mathrm{TH} / \mathrm{THM}$ process intended for mass production.

Fig. 6 shows a simplified synoptic diagram of the most common TH and THM processes based on what is achieved during the process. Several techniques such as wood drying, reconstituted wood processing, and wood shaping have a long industrial tradition, and will not be discussed in this review. Two processes that have been successfully industrialised will be described more in detail: the thermal modification of sawn timber and surface densification.

\section{Thermal modification}

Thermally modified timber is wood at which the composition of the cell wall material and its physical properties are modified by exposure to temperatures greater than $160{ }^{\circ} \mathrm{C}$ and conditions of decreased oxygen availability. There are various procedures to accomplish this process, most of which differ according to the way they 
exclude air/oxygen from the system (Navi \& Sandberg 2012). For example, a steam or nitrogen atmosphere can be used in the kiln, or the wood can be immersed in hot oil. Thermal modification processes can be applied to a wide range of wood species, but they need to be optimised for each species. The property improvements gained are highly dependent on process conditions, treatment intensity (temperature, duration), wood species, and the dimensions of the sawn timber.

The effect of thermal modification on wood properties has been reported in the literature from the beginning of the $20^{\text {th }}$ century, when it was found that drying wood at a high temperature increased its dimensional stability and reduced its hygroscopicity and strength (Tiemann 1915, Koehler \& Pillow 1925, Pillow 1929, Stamm \& Hansen 1937). After the First World War, comprehensive investigations were reported on the influence of kiln drying at moderate temperatures on the strength of wood for the aviation industry in the United States (Wilson 1920).

Thermally modified timber was introduced by Kollmann (1936) and Seborg et al. (1945), but with limited success. Stamm et al. (1946) reported the first systematic attempts to increase the resistance to wooddestroying fungi by heating wood beneath the surface of molten metal at temperatures between 140 and $320{ }^{\circ} \mathrm{C}$. Thunell \& Elken (1948) and Buro (1954) continued the work by Stamm and colleagues by studying the thermal modification of wood in different gaseous atmospheres.

\section{Physical changes in wood due to thermal processing}

Wood degrades faster when heated by steam or water (Millett \& Gerhards 1972, Hillis 1975). The thermal modification processes are mainly conducted in a dry environment in an inert gas or in a moist environment with steam at temperatures from 160 to $240{ }^{\circ} \mathrm{C}$. Under these conditions, the hemicelluloses are hydrolysed, and the crystallinity index of cellulose increases, but lignin is only slightly affected (PelaezSamaniego et al. 2013). The pyrolysis of hemicelluloses, a process that should be avoided, begins at about $270^{\circ} \mathrm{C}$, followed closely by cellulose (Rowell et al. 2009).

The complexity of the process increases as temperature is altered throughout the process. Degrade products form act as catalysts for further reactions, and moisture available for both hydrolysis and catalysts form continuously, moves from the interior to the surfaces of the timber, and evaporates from the material during treatment. Both the physical and chemical environment inside the wood will change throughout the process.

Thermal modification significantly influences the properties of wood, e.g., hygroscopicity and dimensional stability, resistance against fungi and insects, mechanical properties, and properties such as colour, odour, gluability, and coating performance (Tab. 1). Loss of mass of the timber during thermal modification is a typical effect of the process. A decrease in mass up to $20 \%$ can occur depending on type of process. Most properties of thermally modified timber are, similar to the properties of the raw material, affected by the intensity of the heat treatment process, i.e., by the temperature and duration of the process.

Most thermal modification processes, even at mild temperatures, decrease the hygroscopicity of wood, i.e., its capacity for reabsorption of moisture from the air, however, in some cases, the decreased hygroscopicity can be recovered by moistening (Maejima et al. 2015). As a result of the loss of hygroscopic hemicellulose polymers during thermal modification, the equilibrium moisture content is decreased and, consequently, the swelling and shrinking of the wood are drastically decreased. On average, the equilibrium moisture content is decreased to about half the value of the untreated wood. The hygroscopicity of thermally modified timber can vary considerably with varying process parameters. Thermal modification of timber leads to a reduction in strength and the mode of failure, which generally becomes brittle in nature. The mechanical behaviour of thermally modified spruce was investigated by Borrega \& Karenlampi (2008) in relation to mass loss that occurs during thermal modification. At a constant moisture content, the strength, failure strain, and toughness of timber were found to be reduced due to thermal modification. However, the mechanical properties were not only dependent on the mass loss, but also on the relative humidity in the heating atmosphere.

Tab. 1 - Main changes of properties for thermally modified timber compared with untreated timber.

\begin{tabular}{|c|c|}
\hline Desirable property changes & Undesirable property changes \\
\hline Lower equilibrium moisture content & Decreased MOR (and to some extent) MOE \\
\hline Greater dimensional stability & Decreased impact strength \\
\hline Greater durability against decay & Increased brittleness (e.g. complicates machining) \\
\hline Lower thermal conductivity & Decreased hardness (Brinell hardness) \\
\hline \multicolumn{2}{|c|}{ Lower density } \\
\hline \multicolumn{2}{|c|}{ Dark brown colour } \\
\hline \multicolumn{2}{|c|}{ Characteristic smell } \\
\hline \multicolumn{2}{|c|}{ Longer pressing time for gluing } \\
\hline
\end{tabular}

As a function of mass loss, the inelastic ductility and inelastic toughness were lowest when the timber were heated in a dry climate rather than in a moist climate. At a constant ambient humidity, failure strain and toughness were still reduced, but the strength and the stiffness had improved up to a mass loss of $2-3 \%$. This improvement was attributed to the lower equilibrium moisture content of the thermally modified timber when placed in service conditions. Huges et al. (2015) provided a thorough description of the effect of thermal modification on the mechanical properties of timber, especially toughness properties, and the vital role of water and its interaction with the cell wall components.

\section{Commercial thermal modification processes}

Thermal modification of sawn timber, which has been investigated for many years, is now commercialised, mainly in Europe. The first commercial thermal modification unit in Europe was based on the research of Burmester (1973) and started in Germany around 1980 . The process was never industrialised on a great scale (Giebler 1983). Burmester studied the effects of temperature, pressure, and moisture on wood properties in a closed system, and the process was named Feuchte-WärmeDruck (FWD).

The Plato process (Proving Lasting Advanced Timber Option) was developed in the 1980 s by Royal Dutch Shell in the Netherlands, and is now used by the Plato Company in the Netherlands. The retification process for thermal modification was developed in France in the late 1980s. A second French process is named Le Bois Perdure. This process starts with the drying of green timber in an oven. The wood is then heated to $230{ }^{\circ} \mathrm{C}$ in a steam atmosphere (low $\mathrm{O}_{2}$ ), the steam being generated from the water from the green wood. Sawn timber processed by this method have about the same properties as timber from the retification process.

As the boiling points of many natural oils and resins are greater than the temperature required for the thermal modification of timber, the thermal modification in a hot oil bath is a feasible option. The oil heat treatment (OHT) process was developed in Germany, and the process is performed in a closed process vessel.

The most common commercial thermal modification process, named ThermoWood $^{\circledR}$, started in Finland (1993). It has been licenced via the International ThermoWood Association, with many operations throughout Europe and a growing number outside Europe. For example, from 2003 to 2016 , ThermoWood ${ }^{\circledR}$ global production grew nearly seven fold, from $25,797 \mathrm{~m}^{3}$ in 2003 to $179,507 \mathrm{~m}^{3}$ in 2016 (International ThermoWood Association 2016). In 2003, $32 \%$ of the market area was in Finland, with the majority in the rest of Europe (61\%). By 2013 , Finland was in the small minority (7\%), 
Tab. 2 - Examples of thermal modification processes and their processing conditions (modified after Sandberg \& Kutnar 2016). (MC): moisture content; (FWD): Feuchte-Wärme-Druck; (OHT): oil heat treatment; ( $¥)$ : treatment temperature for different stages of the process is separated by “/”.

\begin{tabular}{|c|c|c|c|c|c|c|c|c|}
\hline Process & $\begin{array}{l}\text { App. } \\
\text { Year }\end{array}$ & Trademarks & $\begin{array}{l}\text { Initial } \\
\text { MC (\%) }\end{array}$ & $\begin{array}{c}\text { Temperature }{ }^{(\ddagger)} \\
\left({ }^{\circ} \mathrm{C}\right)\end{array}$ & $\begin{array}{c}\text { Process } \\
\text { duration }(\mathrm{h})\end{array}$ & $\begin{array}{c}\text { Pressure } \\
\text { (MPa) }\end{array}$ & Atmosphere & Comments \\
\hline FWD & 1970 & - & $10-30$ & $120-180$ & $\approx 15$ & $0.5-0.6$ & Steam & Closed system \\
\hline Plato & 1980 & PlatoWood $^{\circledast}$ & $14-18$ & $\begin{array}{c}150-180 / \\
170-190\end{array}$ & $\begin{array}{c}4-5 / \\
70-120 \\
\text { up to } 2 \text { weeks }\end{array}$ & $\begin{array}{l}\text { Super } \\
\text { atmospheric } \\
\text { pressure } \\
\text { (partly) }\end{array}$ & $\begin{array}{l}\text { Saturated } \\
\text { steam/ } \\
\text { heated air }\end{array}$ & A four- stage process \\
\hline ThermoWood & 1990 & ThermoWood $^{\circledast}$ & $\begin{array}{l}10 \text { to } \\
\text { green }\end{array}$ & $\begin{array}{c}130 / \\
185-215 / \\
80-90\end{array}$ & $30-70$ & Atmospheric & Steam & $\begin{array}{l}\text { Continuous steam-flow } \\
\text { through the wood under } \\
\text { processing that removes } \\
\text { volatile degradation } \\
\text { products }\end{array}$ \\
\hline Le Bois Perdure & 1990 & Perdure ${ }^{\circledast}$ & green & $200-230$ & $12-36$ & Atmospheric & Steam & $\begin{array}{l}\text { The process involves } \\
\text { drying and heating the } \\
\text { wood in steam. }\end{array}$ \\
\hline Retification & 1997 & $\begin{array}{l}\text { Retiwood }^{\circledast}, \\
\text { Bois Rétifié }^{\circledast}, \\
\text { Réti }^{\circledast}, \\
\text { Retibois }^{\circledast}, \\
\text { Retitech }^{\circledast}, \\
\text { Retifier }^{\oplus}\end{array}$ & $\approx 12$ & $160-240$ & $8-24$ & - & $\begin{array}{l}\text { Nitrogen or } \\
\text { other gas }\end{array}$ & $\begin{array}{l}\text { The nitrogen atmosphere } \\
\text { guarantees a maximum } \\
\text { oxygen content of } 2 \%\end{array}$ \\
\hline OHT & 2000 & $\mathrm{OHT}^{\oplus}$ & $\begin{array}{l}10 \text { to } \\
\text { green }\end{array}$ & $180-220$ & $24-36$ & - & $\begin{array}{l}\text { Vegetable } \\
\text { oils }\end{array}$ & Closed system \\
\hline $\begin{array}{l}\text { TERMOVUOTO } \\
\text { (thermo-vacuum } \\
\text { treated [TVT] } \\
\text { wood) }\end{array}$ & 2010 & VacWood $^{\circledast}$ & $\begin{array}{l}0 \% \text { (at the } \\
\text { TVT phase) }\end{array}$ & $160-220$ & up to 25 & $\begin{array}{l}\text { Vacuum } \\
150-350 \\
(1000) \mathrm{mbar}\end{array}$ & Vacuum & $\begin{array}{l}\text { Closed system, initial } \\
\text { low-temperature drying } \\
\text { from initial MC in the TV } \\
\text { cylinder }\end{array}$ \\
\hline
\end{tabular}

with the rest of Europe being dominant (76\%) and a small, but growing, portion outside Europe (17\%). The volumes might appear low, but thermal modification technologies align more with value-added niche segments than with commodity products that have minimal processing. During the 12 years of operation from 2001 to 2013 , there was an $18 \%$ increase in the sales per year (Mayes 2014).

The TERMOVUOTO process is a vacuumbased thermal modification technology that has been developed during recent years in an EU-Eco-Innovation initiative project (TV4NEWOOD ECO/12/333079). This thermo-vacuum modification process is an alternative technology for the thermal modification of timber, during which reduction of oxygen inside an air-tight cylinder (the reactor) is obtained by applying a vacuum, while volatiles and water vapour are continuously removed using a vacuum pump. This process exhibits high energy efficiency, lower rate of mass loss, and less corrosion of the process equipment compared to alternative thermal modification technologies (Allegretti et al. 2012). Moreover, the thermo-vacuum system does not cause a considerable reduction of the mechanical properties of timber (Candelier et al. 2014).

Thermal modification processes have also been established in North America. The Perdure process (Le Bois Perdure) was the first process established in Canada, by $\mathrm{PCl}$ Industries, in 2003. Today, there are several industrial plants in the Québec region. The ThermoWood process as well as other thermal modification units are also in production in Canada. In 2012, there were seven manufacturers of thermally modified timber in Canada and 10 in the United States (Sandberg \& Kutnar 2016).

Tab. 2 shows the processing conditions for the previously mentioned thermal modification processes.

Although thermally modified timber can now be used in many common applications, the market is still limited. Thermally modified timber is suitable for various uses, mainly in which it is exposed to weather and humidity variations above ground, e.g., for outside use in cladding, terraces, decking, garden furniture, saunas, and windows, but it is also suitable for interior use, such as kitchen furniture, flooring, decorative panels, and stairs. However, its properties and low strength do not allow it to be used in timber structures. Thermally modified timber was first developed to improve the performance and durability of softwoods, but it has more recently been extended to boost the performance of hardwoods, allowing certain low-durability hardwoods to be used outdoors with no additional protection. Examples of thermally modified hardwood species are birch, aspen, ash, soft maple, tulipwood, and red oak (with the best results from quarter-sawn timber).

\section{Surface densification}

Densification, i.e., transverse compression to achieve permanent deformation of wood cells and, thereby, increased density of low-density species, has been studied in recent decades. The main goal of densifying sawn timber is to increase its hardness and surface abrasion resistance and, in some cases, also to increase its strength. Densifying timber, as reported by Sears (1900) or Seborg et al. (1945), leads to a compression of the wood cells throughout the entire volume of the sawn timber, coining the term "bulk densification". More recently, several studies have focused on densifying not the entire volume, but only the wood cells close to the surface, i.e. surface densification (Fig. 7).

In comparison to bulk densification, surface densification offers several advantages. From a structural perspective, surface-densified timber has a higher material usage efficiency. For some products, the improved dampening characteristics result from the unmodified part of the timber, which is deemed as an asset. In addition, treatments to avoid the moisture-induced recovery of the densified wood cells back to their original shape only need to affect the densified cells close beneath the surface, and not the entire piece of timber. This may allow a faster and, thereby, less costly treatment processes (Neyses 2016).

To create a high-density wood surface, an adequate volume of wood beneath the surface must be softened (Rautkari et al. 2009). Due to the low heat conductivity of wood, local moistening improves the heat transfer into the wood; this helps to soften the moistened region of the wood and improve its compressibility, while the rest of the wood continues to resist compressive deformation (Wang \& Cooper 2005, Lama- 


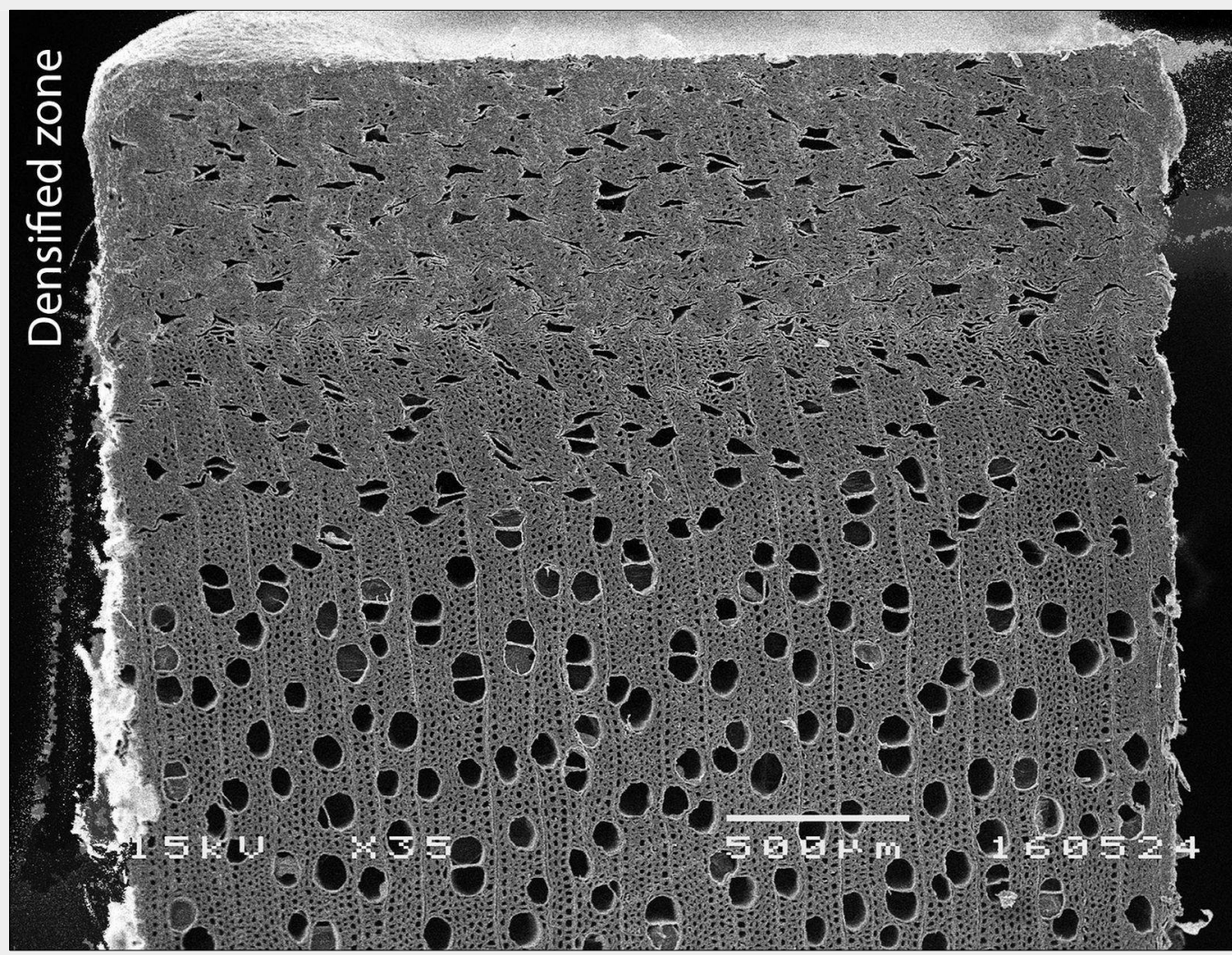

Fig. 7 - Cross-section views of poplar (Populus deltoides Bartr. ex.) at 35× magnification after surface densification showing cell deformation close to the surface.

son \& Gong 2007). Once the desired volume of wood material beneath the surface has been softened, that volume should be compressed via the application of an external load. The main challenges are to steer the densification path so that only the cells just beneath the surface are compressed, and to lock the cells in a compressed state that resists humidity variation in the surroundings.

The first attempts to densify the surface of sawn timber are found in the work of Tarkow \& Seborg (1968), who developed a technique to produce two types of compression deformations during densification: a small elastic compression of the whole wood element, and a large permanent compressive deformation in a thin layer of the surface of the element. The sawn timber was moved between a pair of heated plates at a linear speed of about 8 $\mathrm{m} \mathrm{min}{ }^{-1}$. When the compression set after prolonged periods of high humidification was studied, it showed a distinct compression recovery that was dependent on the pressing conditions, such as temperature, humidity, load level, and pressing time. Although the compression set was stable enough to give the product an industrial application, industrial success did not emerge.

Past studies into surface densification of wood were aimed mainly at exploring different process approaches. Before performing the actual densification in a hot press, Inoue et al. (1990) cut grooves into the wood surface and filled them with water, and subsequently exposed the surface to microwave radiation to plasticise the surrounding wood cells. Pizzi et al. (2005) used a friction-welding machine to densify two pieces of wood at the same time, separated by a layer of oil to avoid bonding. A similar approach was adopted by Rautkari et al. (2009), only using one piece of sawn timber at a time to vibrate on the other, fixed heated steel plate. The vast majority of further studies used a rather simple surface densification process in a hot press.

The reported studies clearly show that it is possible to achieve a significant improvement in several wood properties with surface densification and stabilise the densification effectively, even upon repeated exposure to moisture. However, these approaches rely on time- and energy-consuming batch processes, which means that potential advantages over more expensive wood species or non-renewable materials are lost. For this reason, it is necessary to develop a high-speed surface densification process that is both cost- and energy-efficient.

In an on-going industrial-related project at the Department of Wood Science and Engineering at Luleå University of Technol-

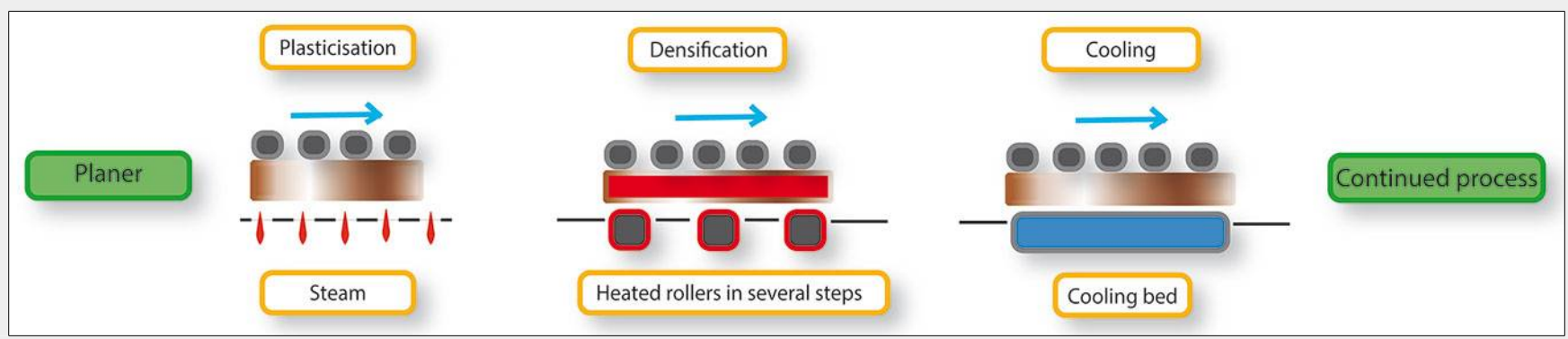

Fig. 8 - The principal setup of the integrated continuous surface densification manufacturing concept (side view). In addition to the plasticisation and densification stages, the pre- and post-treatment stages can be added for the stabilisation of the densified wood, impregnation, colouring, etc. 
ogy, a continuous roller pressing approach was adopted to successfully densify the surface of Scots pine boards at a process speed of up to $80 \mathrm{~m} \mathrm{~min}^{-1}$ (Neyses et al. 2016). The surface densification process is a workflow consisting of dedicated stages, such as plasticisation, densification, solidification, and stabilisation (Fig. 8). The process is intended to be integrated in a continuous production flow, from sawn timber to final products such as flooring. Even if the process stages seem separated, the integrated process takes advantage of possible synergetic effects between the process stages. This manufacturing concept has also been tested with success in a conventional continuous MDF panel press (Sadatnezhad et al. 2017). The press consisted of upper and lower heating devices with four separate adjustable heating sections, two sets of rolling elements to reduce the friction between the stationary heating plates, and movable steel belts. The steel belts transferred heat and pressure to the wood while transporting the wood through the press. The total length of the press was 18 $\mathrm{m}$, with a pressing zone of $6 \mathrm{~m}$.

\section{Life Cycle Assessment}

Though many aspects of wood modification treatments are known, the fundamental influence of the process on product performance, the environment, and end-of-life scenarios remain unknown. To contribute to the low-carbon economy and sustainable development, it is essential to integrate interactive assessments of process parameters, developed product properties, and environmental impacts. To perform objective environmental impact assessments of commercial modification processes and incorporate environmental impact assessments into wood modification processing and product development, including recycling and upgrading at the end of service life, the Life Cycle Assessments (LCA) should be applied.

The common LCA methodology is defined in ISO 14040 (ISO-14040 2006a) and ISO 14044 (ISO-14040 2006b). Since the 1980s, when LCA analysis was first developed, numerous methodologies to classify, characterise, and normalise environmental effects have been developed. The most common are focused on the following environmental impact indicators: acidification, eutrophication, thinning of the ozone layer, various types of ecotoxicity, air contaminants, resource usage, and green-house gas emissions.

The number of LCA studies in the wood sector is relatively limited, geographically distributed, use a variety of databases, and impact assessment protocols (Kutnar \& Hill 2014). Kutnar \& Hill (2014) used a cradle-togate analysis to present the carbon footprint of 14 different primary wood products. The largest source of emissions for all sawn timber products stem from the removal of the timber from the forest, while for kiln dried sawn timber, the drying process follows closely behind. Kutnar \& Hill (2016) discussed the merits of wood as a building material in relation to the environmental benefits of using wood products. Carbon footprints, including sequestered carbon, of wood products with different "end-of-life" scenarios and susceptibility to degradation were compared. They concluded that the interactive assessment of processes parameters, developed product properties, and environmental impact, including recycling and disposal options at the end of the service life, towards up-cycling after their service life based on the cradle-to-cradle concept, are essential research needs that must be further investigated.

Werner \& Richter (2007) reviewed the results of international research on the environmental impact of the life cycle of wood products used in the building sector compared to functionally equivalent products from other materials. The study concluded that fossil fuel consumption, potential contributions to the greenhouse effect, and quantities of solid waste tend to be minor for wood products, compared to competing products. Furthermore, impregnated wood products tend to be more critical than comparative products with respect to toxicological effects and/or photo-generated smog, depending on the type of preservative. Bolin \& Smith (2011a) compared environmental impacts related to boratetreated sawn timber, and concluded that cradle-to-grave life cycle impacts of boratetreated lumber framing were approximately four times less for fossil fuel use, 1.8 times less for GHGs, 83 times less for water use, 3.5 times less for acidification, 2.5 times less for ecological impact, 2.8 times less for smog formation, and 3.3 times less for eutrophication than those for galvanized steel framing. The results of the cradle-to-grave life cycle assessment showed that alkaline-copper-quaternary (ACQ)treated timber impacts were 14 times less for fossil fuel use, almost three times less for GHG emissions, potential smog emissions, and water use, four times less for acidification, and almost half for ecological toxicity than those for wood plastic composite (WPC) decking (Bolin \& Smith 2011b).

Van Der Lugt \& Vogtländer (2014) performed carbon footprint calculations of acetylated timber with system boundaries "cradle to grave" and compared them with those of steel, concrete, and unsustainably sourced azobe. The functional unit was the bearing structure of a pedestrian bridge, with a size of $16 \times 3$ meters. The results showed that acetylated wood has a considerably lower carbon footprint than steel, concrete, and unsustainably sourced azobe, and slightly lower than sustainably sourced azobe. Since the calculation also included carbon sequestration, and due to the limited emissions during production and bio-energy production during the endof-life phase, all sustainably sourced wood alternatives, including acetylated wood, show $\mathrm{CO}_{2}$-negative $\mathrm{LCA}$ results over the full life cycle.

Hill \& Norton (2014) discussed the environmental impact of the wood modification process in relation to life extension of the material. By determination of carbon neutrality they identified the point at which the benefits of life extension compensate for the increased environmental impact associated with the modification. The effect of increased maintenance intervals of modified wood products could be a powerful argument in favour of their use.

Manufacturers of modified wood products, to some extent, have considered the environmental impacts related to their products; some companies have also obtained Environmental Products Declarations (EPDs). However, a more detailed consideration reveals that the global environmental impact of timber modification processing and further uses of the modified wood products are not yet included in the development of processes and products (Kutnar \& Hill 2016). Moreover, their environmental impacts are, to a considerable extent, still unknown, which must change to meet the demands of increasingly conscientious business and consumer markets desiring to make environmentally responsible decisions regarding the goods and services they decide to patronize.

\section{Conclusion}

In this review paper, the development of modified wood according to chemical (acetylation, furfurylation, and impregnation modifications) and thermal-hydro-mechanical processes (thermal modification and surface densification) recently introduced on a European market were discussed. Though many aspects of these modifications are known, the fundamental influence of the process on product performance, the environment, and end-of-life scenarios are still to be included in the research and development of the wood modification technologies. This requires an analysis of the entire value chain, from forest through processing, installation, in-service, end-of-life, second/third life (cascading), and, ultimately, incineration with energy recovery.

Modified wood and the resultant products must place more emphasis on the interactive assessment of process parameters, developed product properties, and environmental impacts. Energy consumption considerably contributes to the environmental impact of modified wood. However, the improved properties during the use phase might reduce the environmental impact of the timber processing. It is important to note that the effective use of wood throughout its whole value chain from forest management, through multiple use cycles and end-of-life disposal, can lead to a truly sustainable development. 


\section{Acknowledgments}

The authors acknowledge COST Action FP1407. Furthermore, the support of Wood Wisdom-Net+ and the Slovenian Ministry of Education, Science, and Sport of the Republic of Slovenia for their support of the Cascading Recovered Wood projects; European Commission for funding the project InnoRenew CoE (\#Grant Agreement 7395 74) under the Horizonz2020 WidespreadTeaming program, and infrastructure program IP-0035; the Swedish Research Council for Environment, the Agricultural Sciences and Spatial Planning (FORMAS), project 942-2016-64 and 2014-172 are also acknowledged.

\section{References}

Adam KD (1951). Der Waldelefant von Lehringen, eine Jagdheute des diluvialen Menschen. [The forest elephant of Lehringen, a hunt for the diluvial man. ] Quartär 5: 79-84. [in German] Alexander J, Hague J, Bongers $F$, Imamura $Y$, Roberts $M$ (2014). The resistance of Accoya ${ }^{\circledR}$ and Tricoya ${ }^{\circledR}$ to attack by wood-destroying fungi and termites. In: Proceedings of the " $45^{\text {th }}$ Annual Meeting of the International Research Group (IRG) on Wood Protection". St. George (Utah, USA) 11-15 May 2014. Document IRG/WP 14/40658, IRG, Stockholm, Sweden, pp. 10. Alfredsen $G$, Ringman R, Pilgård A, Fossdal CG (2015). New insight regarding mode of action of brown rot decay of modified wood based on DNA and gene expression studies: a review. International Wood Products Journal 6 (1): 5-7. doi: 10.1179/2042645314Y.0000000085

Allegretti $O$, Brunetti $M$, Cuccui I, Ferrari S, Nocetti $M$, Terziev N (2012). Thermo-vacuum modification of spruce (Picea abies Karst.) and fir (Abies alba Mill.) wood. BioResources 7 (3): 3656-3669. [online] URL: http://152.1.0.246/in dex.php/BioRes/article/view/BioRes_07_3_365 6_Allegretti_Thermo_Vacuum_Spruce_Fir

Beckers EPJ, Militz H, Stevens M (1994). Resistance of acetylated wood to basiomycetes, soft rot and blue stain. In: Proceedings of the " $25^{\text {th }}$ Annual Meeting of the International Research Group (IRG) on Wood Protection". Bali (Indonesia) 29 May - 3 June 1994. Document IRG/WP 94/40021, IRG, Stockholm, Sweden, pp. 12.

Bolin CA, Smith ST (2011a). Life cycle assessment of borate-treated lumber with comparison to galvanized steel framing. Journal of Cleaner Production 19: 630-639. - doi: 10.1016/j.jclepro. 2010.12.005

Bolin CA, Smith ST (2011b). Life cycle assessment of ACQ-treated lumber with comparison to wood plastic composite decking. Journal of Cleaner Production 19: 620-629. - doi: 10.1016/j.jclepro.2010.12.004

Borrega M, Karenlampi PP (2008). Mechanical behaviour of heat-treated spruce (Picea abies) wood at constant moisture content and ambient humidity. Holz als Roh- und Werkstoff 66: 63-69. - doi: 10.1007/s00107-007-0207-3

Burmester A (1973). Effect of heat-pressure treatments of semi-dry wood on its dimensional stability. Holz als Roh- und Werkstoff 31 (6): 237-243. - doi: 10.1007/BF02607268

Buro A (1954). Die Wirkung von Hitzebehand- lung auf die Pilzresistenz von Kiefern- und Buchenholz [The influence of heat treatment on decay resistance of pine and beech wood]. Holz als Roh- und Werkstoff 12 (8): 297-304. [in German] - doi: 10.1007/BF02606056

Candelier K, Dumarçay S, Pétrissans A, Gerardin $P$, Pétrissans M (2014). Advantage of vacuum versus nitrogen to achieve inert atmosphere during softwood thermal modification. ProLigno 10 (4): 10-17. [online] URL: http://agri trop.cirad.fr/579910/

Dieste A, Krause A, Mai C, Sébe G, Grelier S, Militz H (2009). Modification of Fagus sylvatica L. with 1,3-dimethylol-4,5-dihydroxy ethylene urea (DMDHEU). Part 2: Pore size distribution determined by differential scanning calorimetry. Holzforschung 63: 89-93. - doi: 10.1515/HF. 2009.023

Fuchs W (1928). Genuine lignin. I. Acetylation of pinewood. Berichte 61B: 948-51.

Gérardin P (2016). New alternatives for wood preservation based on thermal and chemical modification of wood - a review. Annals of Forest Science 73: 559-570. - doi: 10.1007/s13595015-0531-4

Giebler E (1983). Dimensionsstabilisierung von Holz durch eine Feuchte/Wärme/Druck-Behandlung [Dimensional stability of wood by a moisture/heat/pressure treatment]. Holz als Rohund Werkstoff 41 (3): 87-94. [in German] - doi: 10.1007/BF02608498

Gindl W, Zargar-Yaghubi F, Wimmer R (2003). Impregnation of softwood cell walls with melamine-formaldehyde resin. Bioresource Technology 87: 325-330. - doi: 10.1016/Sog60-8524 (02)00233-X

Goldstein I (1959). Impregnating solutions and method of impregnation therewith. US Patent 2,909,450, United States Patent and Trademark Office, Alexandria, VA, USA, pp. 4.

Highley TL, Clausen CA, Croan SC, Green F, Illman BL, Micales JA (1994). Research on biodeterioration of wood: I. Decay mechanisms and biocontrol. Research Report FPL-RP-529, Forest Products Laboratory, Madison, WI, USA, pp. 22. Hill CAS (2006). Wood modification - chemical, thermal and other processes. Wiley Series in Renewable Resources, Wiley and Sons, Chichester, UK, pp. 260.

Hill CAS (2009). Why does acetylation protect wood from microbiological attack? Wood Material Science and Engineering 4 (1-2): 37-45. doi: 10.1080/17480270903249409

Hill C, Norton A (2014). The environmental impacts associated with wood modification balanced by the benefits of life extension. In: Proceedings of the "ECWM7 - European Wood Conference on Wood Modification" (Nunes L, Jones D, Hill C, Militz H eds). Lisboa (Portugal), 10-12 March 2014. LNEC - Laboratório Nacional de Engenhara Civil, Lisboa, Portugal, pp. 83. [online] URL: http://www.researchgate.net/pu blication/280877162

Hillis WE (1975). The role of wood characteristics in high temperature drying. Journal of the Institute of Wood Science 7 (2): 60-67.

Homan WJ (2008). Acetylation of wood in lumber thickness. In: "Development of Commercial Wood Preservatives” (Schultz TP, Militz H, Freeman MH, Nicholas DD eds). ACS Symposium Series 982: 324-336. - doi: 10.1021/bk-2008- 0982.ch019

Huges M, Hill C, Pfriem A (2015). The toughness of hygrothermally modified wood. Holzforschung 69 (7): 851-862.

Inoue $\mathrm{M}$, Norimoto $\mathrm{M}$, Otsuka $\mathrm{Y}$, Yamada $\mathrm{T}$ (1990). Surface compression of coniferous wood lumber. I. A new technique to compress the surface layer. Mokuzai Gakkaishi 36 (11): 969-975. [online] URL: http://www.cabdirect.org/cabdirect/abstract/19930671545

Inoue M, Ogata S, Nishikawa M, Otsuka Y, Kawai S, Norimoto M (1993). Dimensional stability, mechanical properties and color changes of a low molecular weight melamine formaldehyde resin impregnated wood. Mokuzai Gakkaishi 39: 181-189.

International ThermoWood Association (2016). Production statistics 2016. International ThermoWood Association, Helsinki, Finland, pp. 7. [online] URL: http://asiakas.kotisivukone.com/ files/en.thermowood.palvelee.fi/uutiset/Produc tionstatistics2016.pdf

ISO-14040 (2006a). ISO 14040 Environmental management - Life cycle assessment - Principles and framework. International Organization for Standardization, Geneva, Switzerland, pp. 20.

ISO-14040 (2006b). ISO 14044 Environmental management - Life cycle assessment - Requirements and guidelines. International Organization for Standardization, Geneva, Switzerland, pp. 46.

Jones D, Hill CAS (2007). Wood modification - a brief overview of the technology. In: Proceedings of the " 5 th $\operatorname{COST}$ E34 International Workshop" (Sernek M ed). Bled (Slovenia) 6-7 Sept 2007. University of Ljubljana, Slovenia, pp. 1-9. Kielmann BC, Militz H, Adamopoulos S (2012). Combined $\mathrm{N}$-methylol melamine colouring agent modification of hardwoods to improve their performance under use-class 3. In: Proceeding of "ECWM6 $-6^{\text {th }}$ European Conference on Wood Modification" (Jones D, Petrič M, Paclič M eds). Ljubljana (Slovenia) 17-18 Sept 2012. University of Ljubljana, Slovenia, pp. 437-446. [online] URL: http://www.diva-portal.org/sma sh/record.jsf?pid=divaz:800900\&dswid $=427$

Kielmann BC, Adamopoulos S, Militz H, Mai C (2014). Decay resistance of ash, beech and maple wood modified with $\mathrm{N}$-methylol melamine and a metal complex dye. International Biodeterioration and Biodegradation 89: 110114. - doi: 10.1016/j.ibiod.2014.01.011

Koehler A, Pillow MY (1925). Effect of high temperatures on the mode of fracture of a softwood. Southern Lumberman 121 (1576): 219-221. Kollmann F (1936). Technologie des Holzes [Wood technology]. Verlag von Julius Springer, Berlin, pp. 788. [in German]

Krause A, Jones D, van der Zee M, Militz $H$ (2003). Interlace treatment - wood modification with N-methylol compounds. In: Proceedings of the "ECWM1 - First European Conference on Wood Modification" (van Acker J, Hill C eds). Ghent University, Belgium, 3-4 April 2003, pp. 317-328.

Krause A, Militz H (2009). Process for improving the durability, dimensional stability and surface hardness of a wood body. US Patent 7,595,116 B2, United States Patent and Trademark Office, Alexandria, VA, USA, pp. 5. 
Kutnar A, Hill C (2014). Assessment of carbon footprinting in the wood industry. In: "Assessment of carbon footprint in different industrial sectors. Volume 2: EcoProduction" (Muthu SS ed). Springer, Singapore, pp. 135-172. - doi: 10.1007/978-981-4585-75-0_6

Kutnar A, Hill C (2016). End of life scenarios and the carbon footprint of wood cladding. In: "The Carbon Footprint Handbook" (Muthu SS ed). CRC Press, Boca Raton, FL, USA, pp. 85-100.

Lamason C, Gong M (2007). Optimization of pressing parameters for mechanically surfacedensified aspen. Forest Products Journal 57 (10): 64. [online] URL: http://search.proquest. com/openview/f350c6cbf2849ca8b7f44beo50e $903 \mathrm{eb} / 1$

Lande S (2008). Furfurylation of wood - Wood modification by the use of furfuryl alcohol. PhD thesis, Norwegian University of Life Science, Ås, Norway, pp. 194.

Lande S, Westin M, Schneider M (2004). Properties of furfurylated wood. Scandinavian Journal of Forest Research 19 (5): 22-30. - doi: 10.1080/ 0282758041001915

Lande S, Eikenes $M$, Westin $M$, Schneider $M$ (2008). Furfurylation of wood: chemistry, properties and commercialization. In: "Development of Commercial Wood Preservatives" (Schultz TP, Militz H, Freeman MH, Nicholas DD eds). ACS Symposium Series 982: 337-355. - doi: 10.1021/bk-2008-0982.ch020

Larsson-Brelid P, Simonson R, Bergman O, Nilsson $T$ (2000). Resistance of acetylated wood to biological degradation. Holz als Roh- und Werkstoff 58 (5): 331-337. - doi: 10.1007/s001070050 439

Larsson-Brelid P (2013). Benchmarking and stateof-the-art report for modified wood. SP Report no. 54, SP Technical Research Institute of Sweden, Stockholm, Sweden, pp. 1-31. [online] URL: http://www.diva-portal.org/smash/get/diva2:96 2771/FULLTEXT01.pdf

Li W, Ren D, Zhang X, Wang H, Yu Y (2016). The furfurylation of wood: a nanomechanical study of modified wood cells. BioResources 11 (2): 3614-3625. [online] URL: http://152.1.0.246/in dex.php/BioRes/article/view/BioRes_11_2_3614 Lukowsky D (1999). Holzschutz mit Melaminharzen [Wood protection with melamine resins]. PhD thesis, University of Hamburg, Germany, pp. 193. [in German]

Maejima H, Endo K, Obataya E (2015). Effects of moistening treatment on the hygroscopicity and the vibrational properties of aged wood. In: Proceedings of the "International Association of Wood Products Societies (IAWPS) International Symposium on Wood Science and Technology". Tower Hall Funabori, Tokyo (Japan) 15-17 March 2015, pp. 247.

Mantanis G, Lykidis C (2015). Evaluation of weathering of furfurylated wood decks after a 3-year outdoor exposure in Greece. Drvna Industrja 66 (2): 115-122. - doi: 10.5552/drind.2015. 1425

Mantanis G (2017). Chemical modification of wood by acetylation or furfurylation: a review of the present scaled-up technologies. BioResources 12 (3): 115-122. - doi: 10.15376/biores.12. 2.Mantanis

Mayes D (2014). The evolution of thermally modified timber and beyond. Presentation given at
Forest Industry Engineering Association (FIEA) event "Wood Innovations 2014" Melbourne (Australia), 23-24 Sept 2014.

Militz H (1991). The improvement of dimensional stability and durability of wood trough treatment with non-catalysed acetic acid anhydride. Holz als Roh- und Werkstoff 49 (4): 147-152. doi: 10.1007/BF02607895

Militz H (1993). Treatment of timber with water soluble dimethylol resins to improve their dimensional stability and durability. Wood Science and Technology 27: 347-355. - doi: 10.1007/ BFo0192221

Millett MA, Gerhards CC (1972). Accelerated aging: residual weight and flexural properties of wood heated in air at $115{ }^{\circ} \mathrm{C}$ to $175{ }^{\circ} \mathrm{C}$. Wood Science 4 (4): 193-201.

Mohebby B, Militz H (2010). Microbial attack of acetylated wood in field soil trials. International Biodeterioration and Biodegradation 64: 41-50. - doi: 10.1016/j.ibiod.2009.10.005

Navi P, Sandberg D (2012). Thermo hydro mechanical processing of wood. EPFL Press, Lausanne, Switzerland, pp. 376.

Neyses B (2016). Surface-densified wood: from laboratory-scale research towards a competitive product. Licentiate thesis, Wood Science and Engineering, Luleå University of Technology, Skellefteå, Sweden, pp. 59. [online] URL: http://www.diva-portal.org/smash/record.jsf? pid=diva2:1045759\&dswid=-1791

Neyses B, Hagman O, Nilsson A (2016). Development of a continuous wood surface densification process: the roller pressing technique. In: Proceedings of the " $59^{\text {th }}$ International Convention of Society of Wood Science and Technology. Forest Resource and Products: Moving Toward a Sustainable Future" (LeVan-Green S ed). Curitiba (Brasil) 6-10 March 2016, pp. 17-24. Nicholas DD, Williams AD (1987). Dimensional stabilization of wood with dimethylol compounds. In: Proceedings of the "International Research Group on Wood Protection". Honey Harbour, Ontario (Canada) 17-22 May 1987. Document IRG/WP 3412, IRG, Stockholm, Sweden, pp. 10.

Nordstierna L, Lande S, Westin M, Karlsson O, Furo I (2008). Towards novel wood-based materials: chemical bonds between lignin-like model molecules and poly (furfuryl alcohol) studied by NMR. Holzforschung 62 (6): 709-713. - doi: 10.1515/HF.2008.110

Papadopoulos AN, Hill CAS (2002). The biological effectiveness of wood modification with linear chain carboxylic acid anhydrides against Coniophoraputeana. Holz als Roh- und Werkstoff 60: 329-332. - doi: 10.1007/s00107-002-0327-8

Papadopoulos AN (2010). Chemical modification of solid wood and wood raw material for composites production with linear chain carboxylic acid anhydrides: a brief review. BioResources 5 (1): 499-506.

Papadopoulos AN, Mantanis G (2012). Vapour sorption studies of Belmadur wood. Advances in Forestry Letter 1 (1): 1-6. [online] URL: http:// www.researchgate.net/publication/234102006 Pelaez-Samaniego MR, Yadama V, Lowell E, Espinoza-Herrera R (2013). A review of wood thermal pretreatments to improve wood composite properties. Wood Science and Technology 47: 1285-1319. - doi: 10.1007/s00226-013-057
4-3

Pilgård A, Treu A, Zeeland V, Gosselink JA, Westin M (2010). Toxic hazard and chemical analysis of leacheates from furfurylated wood. Environmental Toxicology Chemistry 29: 19181924.

Pillow MY (1929). Effect of high temperatures on the mode of fracture and other properties of a hardwood. Southern Lumberman 137 (1766): 58-60.

Pittman C, Kim MG, Nicholas DD, Wang L, Kabir FRA, Schultz TP, Ingram LL (1994). Wood enhancement treatments. I. Impregnation of southern yellow pine with melamine formaldehyde and melamine-ammeline formaldehyde resins. Journal of Wood Chemistry and Technology 14 (4): 577-603. - doi: 10.1080/02773819408 003114

Pizzi A, Leban JM, Zanetti M, Pichelin F, Wieland $S$, Properzi M (2005). Surface finishes by mechanically induced wood surface fusion. Holz als Roh- und Werkstoff 63 (4): 251-255. - doi: 10.1007/s00107-004-0569-8

Rapp A, Peek RD (1999). Melaminharzimprägniertes so wiemitWetterschutzlasuro-berflächenbehandeltes und unbehandeltes Vollholz während zweijähriger Freilandbewitterung [Melamine resin treated as well as varnish coated and untreated solid wood during drying two years of natural weathering]. Holz als Rohund Werkstoff 57: 331-339. [in German] - doi: 10.1007/s001070050353

Rautkari L, Properzi M, Pichelin F, Hughes M (2009). Surface modification of wood using friction. Wood Science and Technology 43(3-4): 291-299. - doi: 10.1007/s00226-008-0227-0

Ringman R, Pilgård A, Richter K (2015). In vitro oxidative and enzymatic degradation of modified wood. International Wood Products Journal 6 (1): 36-39. - doi: 10.1179/2042645314Y.00oo 000080

Rowell RM (1983). Chemical modification of wood: a review. Commonwealth Forestry Bureau, Oxford, UK, vol. 6, pp. 363-382.

Rowell RM, Simonson R, Hess S, Plackett DV, Cronshaw D, Dunningham E (1994). Acetyl distribution in acetylated whole wood and reactivity of isolated wood cell wall components to acetic anhydride. Wood and Fiber Science 26 (1): 11-18.

Rowell RM, Ibach RE, McSweeny J, Nilsson T (2009). Understanding decay resistance, dimensional stability and strength changes in heat treated and acetylated wood. Wood Material Science and Engineering 4(1-2): 14-22. - doi: $10.1080 / 17480270903261339$

Rowell RM (2012). Handbook of wood chemistry and wood composites ( $2^{\text {nd }}$ edn). CRC Press, Taylor and Francis Group, Boca Raton, FL, USA, pp. 703. [online] URL: http://books.google.com/ books?id=QMn6rsl_PPgC

Rowell RM (2014). Acetylation of wood - a review. International Journal of Lignocellulosic Products 1 (1): 1-27. [online] URL: http://ijlp.gau.ac.ir/article_1920.html

Rowell RM (2016). Dimensional stability and fungal durability of acetylated wood. Drewno 59 (197): 139-150. [online] URL: http://agro.icm.edu.pl/agro/element/bwmeta1.element.agroa3870964-67d8-4616-a850-23474df2b1d2/c/C14_139.pdf 
Sadatnezhad SH, Khazaeian A, Sandberg D, Tabarsa T (2017). Continuous surface densification of wood: a new concept for large-scale industrial processing. BioResources 12 (2): 31223132. - doi: 10.15376/biores.12.2.3122-3132

Sandberg D, Haller P, Navi P (2013). Thermo-hydro and thermo-hydro-mechanical wood processing: An opportunity for future environmentally friendly wood products. Wood Material Science and Engineering 8 (1): 64-88. - doi: 10.1080/17480272.2012.751935

Sandberg D, Kutnar A (2016). Thermal modified timber: recent developments in Europe and North America. Wood and Fiber Science 48 (1): 28-39. [online] URL: http://wfs.swst.org/index. php/wfs/article/view/2296

Scheider MH (1995). New cell wall and cell lumen wood polymer composites. Wood Science and Technology 29: 121-127.

Sears CU (1900). Preparing wood matrices. US Patent No. 646547, United States Patent and Trademark Office, Alexandria, VA, USA, pp. 3.

Seborg R, Millet M, Stamm A (1945). Heat-stabilized compressed wood - Staypack. Mechanical Engineering 67: 25-31.

Sint KM, Adamopoulos S, Koch G, Hapla F, Militz $H$ (2013). Impregnation of Bombax ceiba and Bombax insigne wood with a $\mathrm{N}$-methylol melamine compound. Wood Science and Technology 47: 43-58. - doi: 10.1007/s00226-012-0482-y Stamm AJ, Hansen LA (1937). Minimizing wood shrinkage and swelling. Effect of heating in various gasses. Industrial and Engineering Chemistry 29 (7): 831-833. - doi: 10.1021/ie50331a021 Stamm AJ, Burr HK, Kline AA (1946). Staybwood. Heat stabilized wood. Industrial and Engineering Chemistry 38 (6): 630-634. - doi: 10.1021/ie $50438 \mathrm{a} 027$
Stamm AJ, Seborg RM (1955). Forest products laboratory resin-treated wood (impreg). Research Report no. 1380, Forest Products Laboratory, Madison, WI, USA, pp. 10.

Stamm AJ (1977). Dimensional stabilization of wood with furfuryl alcohol. In: "Wood technology: Chemical aspects" (Goldstein I ed). ACS Symposium Series, Vol. 43. American Chemical Society, Washington, DC, USA, pp. 141-149. doi: 10.1021/bk-1977-0043.choog

Tarkow H (1946). A new approach to the acetylation of wood. Forest Products Laboratory, USDA Forest Service, Madison, WI, USA, pp. 9. Tarkow H, Seborg R (1968). Surface densification of wood. Forest Products Journal 18 (9): 104107.

Thunell B, Elken E (1948). Värmebehandling av trä för minskning av svällning och krympning [Heat treatment of wood for decreased swelling and shrinkage]. Report No. 18, The Swedish Wood Technology Research Institute, Stockholm, Sweden, pp. 23. [in Swedish]

Thygesen LG, Barsberg S, Venås TM (2010). The fluorescence characteristics of furfurylated wood studied by fluorescence spectroscopy and confocal laser scanning microscopy. Wood Science and Technology 44 (1): 51-65. - doi: 10.1007/s00226-009-0255-4

Tiemann HD (1915). The effect of different methods of drying on the strength of wood. Lumber World Review 28 (7): 19-20.

United Nations (2015). Paris agreement. UN, New York, USA, pp. 25. [online] URL: http:// unfccc.int/files/essential_background/convention/application/pdf/english_paris_agreement.pdf

Van Der Lugt P, Vogtländer JG (2014). Wood acetylation: a potential route towards climate change mitigation. WIT Transactions on Ecology on The Built Environment, Eco-Architecture V 142: 241-252. - doi: 10.2495/ARC140221

Van Der Lugt P, Bongers F, Vogtländer J (2016). Environmental impact of constructions made of acetylated wood. In: Proceedings of the "WCTE 2016 - World Conference on Timber Engineering". Vienna (Austria) 22-25 Aug 2016, pp. 1-6. [online] URL: http://www.researchgate.net/ publication/307512746

Wang JY, Cooper PA (2005). Effect of grain orientation and surface wetting on vertical density profiles of thermally compressed fir and spruce. Holz als Roh- und Werkstoff 63 (6): 397402. - doi: 10.1007/s00107-005-0034-3 Werner F, Richter K (2007). Wood building products in comparative LCA. A literature review. International Journal of LCA 12 (7): 470-479.

Westin M, Nilsson T, Hadi, YS (1998). Field performance of furfuryl alcohol treated wood. In: Proceedings of the " $4^{\text {th }}$ Pacific Rim Bio-Based Composites Symposium” Bogor (Indonesia) 2-5 Nov 1998. Bogor Agricultural University, Bogor, West Indonesia, pp. 305-331.

Westin M, Larsson-Brelid P, Nilsson T, Rapp A, Dickerson JP, Lande S, Cragg S (2016). Marine borer resistance of acetylated and furfurylated wood - Results from up to 16 years of field exposure. In: Proceedings of the " $47^{\text {th }}$ Annual Meeting of the International Research Group (IRG) on Wood Protection". Lisbon (Portugal) 15-19 May 2016. Document IRG/WP 16-40756, IRG, Stockholm, Sweden, pp. 10.

Wilson TRC (1920). The effect of kiln drying on the strength of airplane woods. Report No. 68, National Advisory Committee for Aeronautics, Washington, DC, USA, pp. 79. [online] URL: http://ntrs.nasa.gov/search.jsp?R=19930091130 